\title{
Urbanization and Quality of Urban Environment Using Remote Sensing and GIS Techniques in East Delhi-India
}

\author{
Atiqur Rahman', Yogesh Kumar', Shahab Fazal', Sunil Bhaskaran ${ }^{3}$ \\ ${ }^{1}$ Department of Geography, Faculty of Natural Sciences, Jamia Millia Islamia University, New Delhi, India \\ ${ }^{2}$ Department of Geography, Faculty of Science, Aligarh Muslim University, Aligarh, India \\ ${ }^{3}$ Remote Sensing and GIS Division, Department of Environmental, Geographic and Geological Sciences, \\ Lehman College, City University of New York, Bronx, USA \\ E-mail: ateeqgeog@yahoo.co.in
}

Received November 12, 2010; revised December 14, 2010; accepted December 27, 2010

\begin{abstract}
An explosive increase of urban population, practically in all major cities and towns, has the consequent strain on the existing system manifested in an environmental chaos. The phenomena of accelerated urbanisation is the main culprit, wherein besides bringing higher standard of living, it has also brought problems, as growth of dense and unplanned residential areas, environmental pollution, non-availability of services and amenities, solid waste etc. Remote sensing satellite data is suitable for urban land use mapping to get detail and upto-date information for environmental management. Where as GIS helps in developing database system for urban information, which supports decision making process. Development of digital database on all aspects of land use and urban planning is the next crucial task for the future in which remote sensing based information is going to play a major role. In Delhi, rise in population and growth in economic activity has led to environmental degradation. With this view an attempt has been made to study the quality of urban environment in the East district of Delhi, which is experiencing very high urban growth with $98.75 \%$ urban population in 2001. For this study Landsat ASTER (MSS) data of year 2001 (15 m Ground resolution), Guide map of the year 1982 and demographic and environmental data has been used. Eight parameters were selected, which affect the urban environmental quality, namely built-up area, open spaces, household density, occupancy ratio, population density, accessibility to roads, noise and smell affected area. The study shows that the quality of environment has been degraded when we compare 1982 and 2003 data. Most of the East district was in a better state of environment in 1982, but in 2003 things have been changed and now 50\% area is in very good, fair and desirable condition. The public participation and involvement should be encouraged planning and decisions making for the improvement in better urban environmental quality.
\end{abstract}

Keywords: Urbanization, Urban Environmental Quality, Remote Sensing \& GIS, East Delhi-India

\section{Introduction}

Urban growth all over the world is taking place which is unequal but the rate of urbanization is very fast in the developing countries especially in Asia. In 1800 A.D, only $3 \%$ of the world's population lived in urban centres and this figure reached to $14 \%$ in 1900 and in 2000, about $47 \%$ ( 2.8 billion) people were living in urban areas. India no longer lives in villages and 79 million people were living in urban areas in India in 1961 but in 2001 about 285 million people resides in urban areas [1]. In 1991, there were 23 metropolitan cities in India [2] which increased to 35 in 2001 [3] some of the prominent are Mumbai, Delhi, Kolkatta and Chennai etc. As urban population increases, the demand of land for various urban activities also increases. In India the process of urbanization gained momentum with the start of industrial revolution and globalization way back in 1970s. Forests were cleared, grasslands ploughed or grazed, wetlands drained and croplands encroached upon under the influence of expanding cities, yet never as fast as in the last decade. The main basis of urbanization is the economic change and in particular the growth of secondary and tertiary occupation in urban areas [4]. 
The high rate of increase in the urban population has created many problems in the urban areas of Indian cities. Doubling and tripling of urban population practically in all major cities and towns and the consequent strain on the existing system manifested in an environmental chaos. Every major city of India faces the same proliferating problems of urban expansion, inadequate housing, poor transportation system, poor sewerage, erratic electric supply, insufficient drinking water supplies etc. An increasing number of trucks, buses, cars, three-wheelers and motorcycles all spewing uncontrolled fumes, surge in sometimes-haphazard patterns over city streets jammed with jaywalking pedestrians, rickshaw, cattle, and goats. The phenomena of accelerated urbanization is the main culprit, wherein besides bringing higher standard of living has also brought problems of growth of dense and unplanned residential areas, environmental pollution, non-availability of services and amenities and solid waste generation and growth of slums. The rapid growth of Delhi in past decades has resulted in significant decrease in the quality of environment. Rise in population and growth in economic activity has led to environmental degradation in Delhi. Emerging future of Delhi in the light of its past experiences, current trends, and development initiatives is one of the important issue which shows different social and physical factors affecting the housing and quality of life in Delhi [5]. After independence, when Delhi witnessed a large influx of migrants, within a very short time, the population of Delhi increased more than two folds. To house such a large migrant people city has to expand but the rate of expansion is very fast, unplanned, uncontrolled and most of them are illegal [6].

Each urban centre has a number of environmental problems with varying scale and scopes which are influenced by factors such as size of population and its density, climatic conditions, water resources and the flora and fauna in and around the urban centre [1]. The state of urban environment all over India is deteriorating so fast that the sustainability of the cities is threatened. In metro cities, land environment is under stress due to the pressure of rapid urbanization. Population growth and in-migration of poor people, industrial growth, inefficient and inadequate traffic corridors, poor environmental infrastructure, etc. are the main factors that have deteriorated the overall quality of the city environment. As the cities expand and population increases, the resources, which are limited, are shared. Housing, water supply, roads, drainage, transport, education, health services, police and fire services, etc. have not been able to keep pace with the prevailing urban growth rate that leads to degrading urban environmental quality.

The quality of environment of an urban area is deter- mined by the intricate process of mankind's making living an enjoyable one. One of the more interesting questions with regard to urban environmental quality is how to assess it, objectively and comparatively, the quality of a city's built-up area. Is it the environmental quality of an isolated residential building or that of a residential complex or a neighbourhood? Some city dwellers may instinctively define what environmental quality means for them: they would emphasize the need for cleanliness in the streets and around the trash dumpsters, they would mention noise problems caused by a variety of sources, they would describe the lack of certain services, and so on.

There are many approaches discussed and compared for housing quality studies and environmental assessment. Social and physical environment of the Durgapur city had been assessed by observing the effect of air quality on land use pattern and population density using overlay method [7]. The white paper of Delhi describes the state of urban environment of Delhi and worked out for assessing the pollution trends and the prescribed ambient standards [8]. The quality of urban environment is determined from two directional approaches one is the 'Total City Environment' and the other is 'Appraisal of Individual Buildings' i.e., quality of life and quality of development respectively [9]. In present study the 'Quality of Urban Environment' is assessed from the 'Total City Environment Approach' i.e., Quality of Life.

In order to objectively evaluate the quality of a home in a particular environment compared with a home in another part of the city, we would need objective data and a precise measuring tool. The application of remote sensing data as well as its integration in GIS domain provides planners and implementing agencies timely information on various aspects. Information acquired through spatial technologies not only helps in the environmental and urban planners during policy formulation and in implementation process, but also provides valuable database for monitoring and future planning purposes. Indian satellite data from sensors like IRS-1D, LISS-III MSS and PAN merged products can be very useful in urban analysis and urban land use mapping [10]. Digital Mapping Technique has been applied for information generation and making an up-to-date urban information [11]. The quality of urban residential environment of Ujjain city has been assessed using aerial remote sensing and limited field survey in reference of physical parameters by 'Overlay' and 'Assigning value to variables' method, i.e., 'Appraisal of individual buildings approach' or Quality of Development [12]. An attempt has been made to reconcile the differences between the typical approaches to Multi Criteria Evaluation used in Vector and Raster GIS [13]. Buffer analysis of 
physical parameters, which are identified and mapped from aerial photographs and limited field checks, and estimation of the affected population are applied to assess the quality of urban environment of Dwarka in Delhi [14]. Temperature data, derived from Landsat $\mathrm{ETM}^{+}$, Vegetation Index (VI) derived from high resolution IKONOS multi-spectral images, digitized data of the city urban infrastructure and 3-D virtual reality models were integrated to assess urban environment quality of Hong Kong [9]. The change of urban environment and its impact have direct repercussion on the people and their living condition. Therefore, it was thought to assess the quality of urban environment in one of the fastest growing district of Delhi with the help of remote sensing and GIS technique.

\section{Objectives}

The main objective of the paper is assessing the environmental quality in East district of Delhi Metropolitan Region (DMR) using physical and other parameters, which are derived from remote sensing satellite and secondary data. The specific research objectives of the paper are 1) to assess the changing pattern of environmental quality 2) to evaluate the urban environment both qualitatively and quantitatively by using weighted overlay method and lastly 3) to recognize the factors leading to such conditions and to evaluate the possibilities of improvement of urban environment by public participation.

\section{Study Area: East Delhi-India}

Delhi, the capital of India spreads over an area of 1,463 sq. km. East District of Delhi is located on the eastern side of river Yamuna between $28^{\circ} 34^{\prime} 47^{\prime \prime}$ to $28^{\circ} 40^{\prime} 47^{\prime}$ ' $\mathrm{N}$ latitude and $77^{\circ} 15^{\prime} 05^{\prime}$ ' to $77^{\circ} 20^{\prime} 37^{\prime}$ ' E longitude Figure 1, having an area of about $64 \mathrm{~km}^{2}$. It is flanked by Gaziabad and NOIDA district of Uttar Pradesh in east and south respectively. Among the nine Districts, East district has three tehsil, Geeta Colony, Vivek Vihar and Preet Vihar, 25 administrative blocks (Figure 2) and has three villages (Vill), five Census towns (CT) apart from Delhi Municipal Corporation's Sahadara Zone. The East district of Delhi was chosen for this study to asses the quality of urban environment because it is the one of the populous district and developing very fast.

East District is entirely located on the eastern side Yamuna plain, which used to be a very fertile levelled land but it is fast converting in to built-up areas. The climate is semi-arid with maximum rain fall in the month of July (296 mm), October to December are dry. While the hottest months are May and June with mercury levels touching $48^{\circ} \mathrm{C}$ whereas the lowest falls to $4^{\circ} \mathrm{C}$ at the end of December and early January. The total Delhi population was nearly 0.4 million in 1901 , which kept on increasing slowly and it was 1.74 million in 1951 and 9.42 million in 1991. Sharp rise in population occurred in the last decade (1991-2001) and Delhi population reached to 13.8 million in 2001 [3] and as per Registrar General of India (RGI) estimates Delhi's population will be 20.78 million by 2015 [15]. East district has been experiencing very high growth rate of urban population and it ranks $6^{\text {th }}$ among all districts with $90.19 \%$ urban population in 1991, while $98.75 \%$ urban population growth recorded in 2001, which is only after Central and New Delhi Districts

\subsection{Pattern of Urbanization in Delhi}

As the national capital Delhi has drawn people from all parts of India. Delhi is mini India with the largest number of immigrant communities who have made it their home. Delhi has witnessed a phenomenal population growth during past few decades. From a population of 0.46 million in 1901, its population has grown to 13.78 million in 2001 [3] (Figure 3). There was sudden increase in the population in 1947, as a result of partitions of India and Pakistan. The 1941-51 decade recorded a growth of $90 \%$. Since 1951, the population of Delhi has been increasing at an average rate of about $50 \%$ every decade (Table 1).

In the 1901 Census, more than $47.34 \%$ of Delhi's population lived in rural areas which showed a gradual decline $17.60 \%$ in 1951 to $6.99 \%$ in 2001 (Table 2). Although, there has been a slight reversal of the trend, i.e., $10.07 \%$ in 1991 . Urbanisation has increased rapidly since 1911 when the capital of India was sifted from Calcutta (presently Kolkata) to Delhi. The pace of urbanisation was accelerated during 1941-51 when the country was divided into India and Pakistan and a large number of migrant settled in Delhi. With rapid urbanisation, the rural area is shrinking; it has reduced from $1157.52 \mathrm{sq}$ $\mathrm{km}$ in 1961 to $591.91 \mathrm{sq} \mathrm{km}$ in 2001. In 2001 the population density was 14,387 and 1,627 persons $/ \mathrm{km}^{2}$ in urban areas and rural areas respectively. Villages of Delhi, which have coexisted with the sprawling urban settlements, still retain a great deal of rural tradition.

The rapid urbanisation has led to the development of new settlements colonies in Delhi. These settlements are categorised by Delhi Development Authority (DDA) in terms of civic infrastructure, types of houses, authorised vs. unauthorised settlement etc, Jhuggis and Jhoparis (informal) resettlement colonies, Slum resettlement colonies, Refugee resettlement colonies, Approved/ planned colonies, Unauthorised-regularised colonies, Urbanised colonies, Urbanised villages, Notified slum 


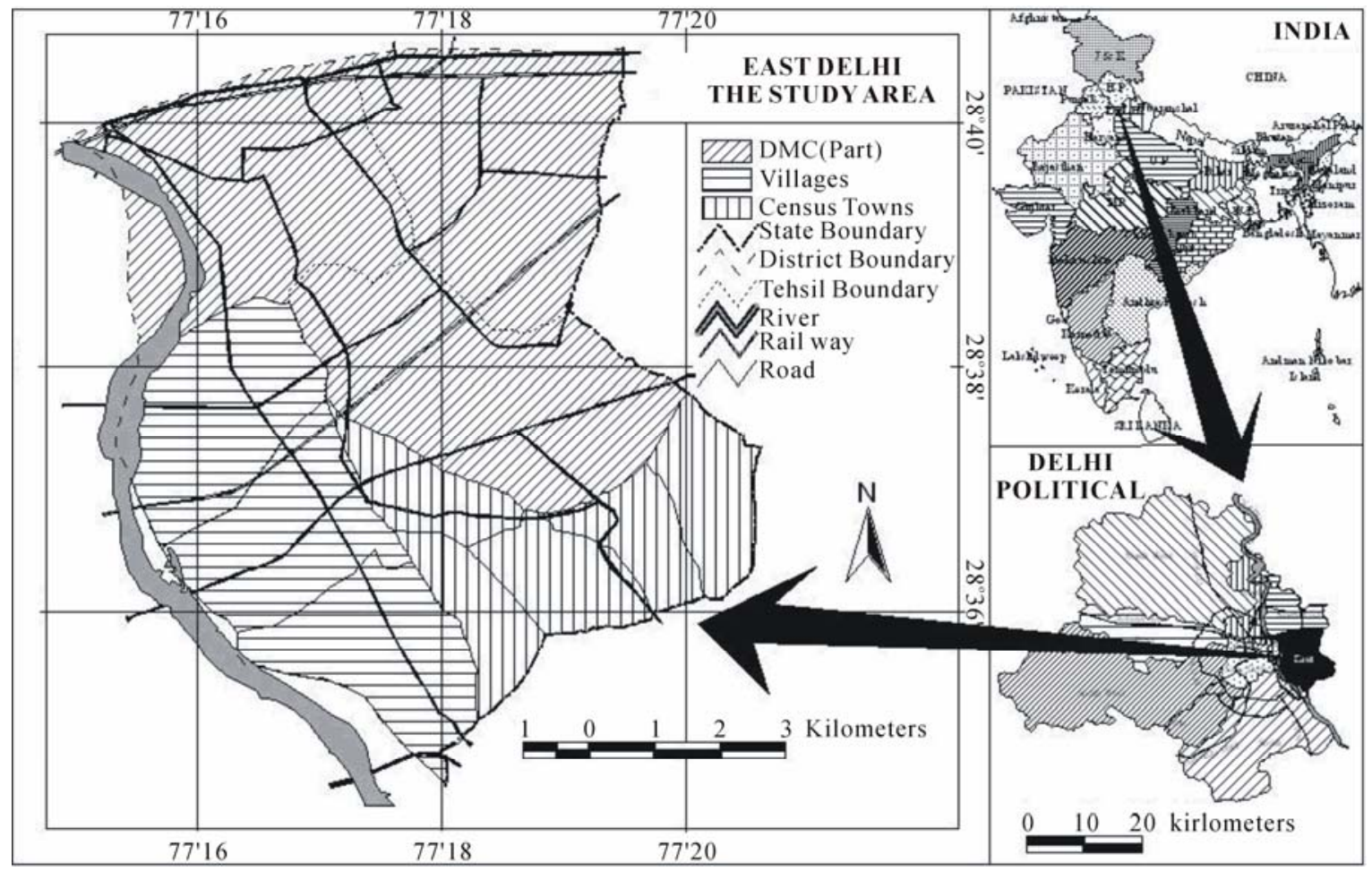

Figure 1. Locational aspect of study area.

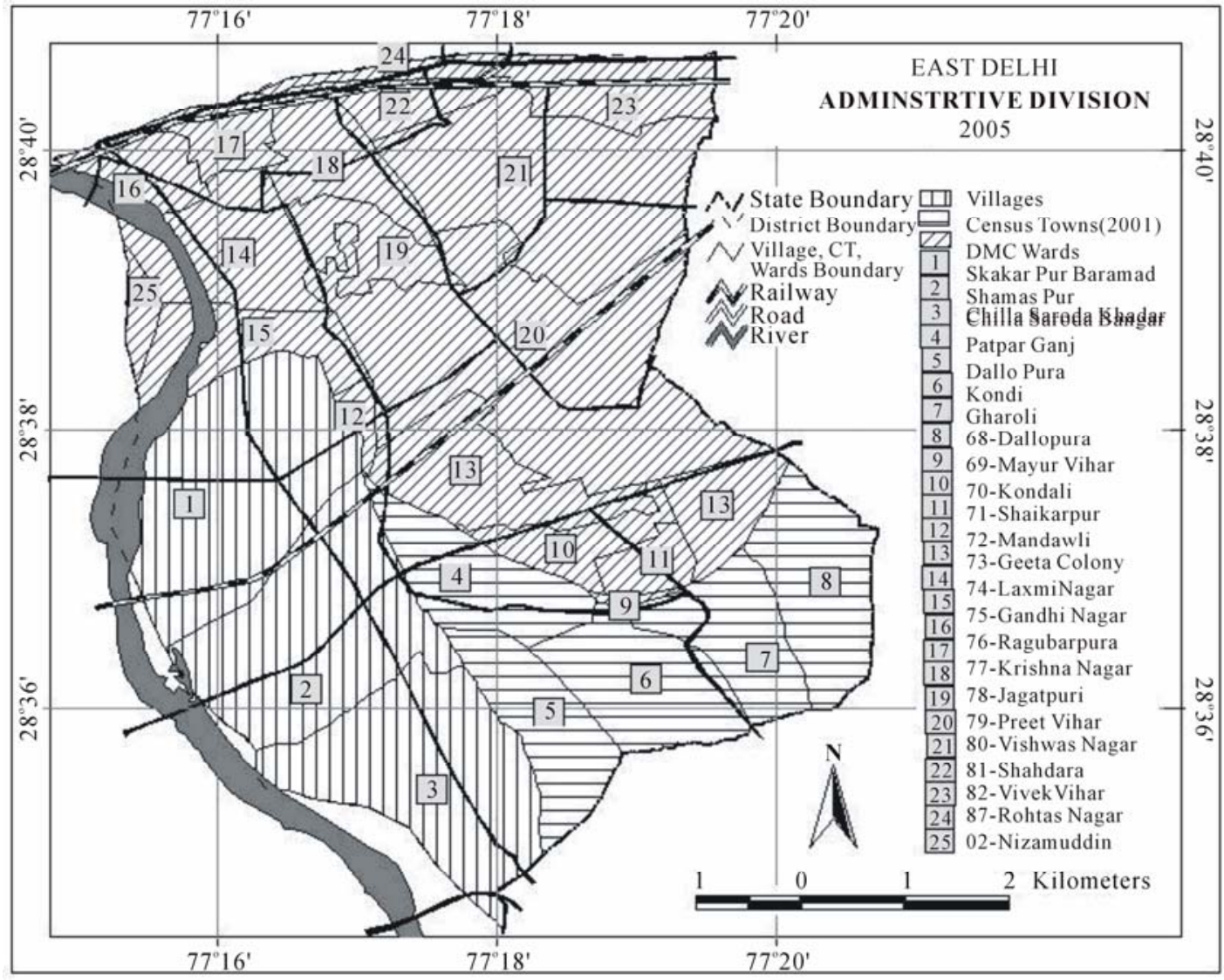

Figure 2. Administrative divisions of east Delhi. 


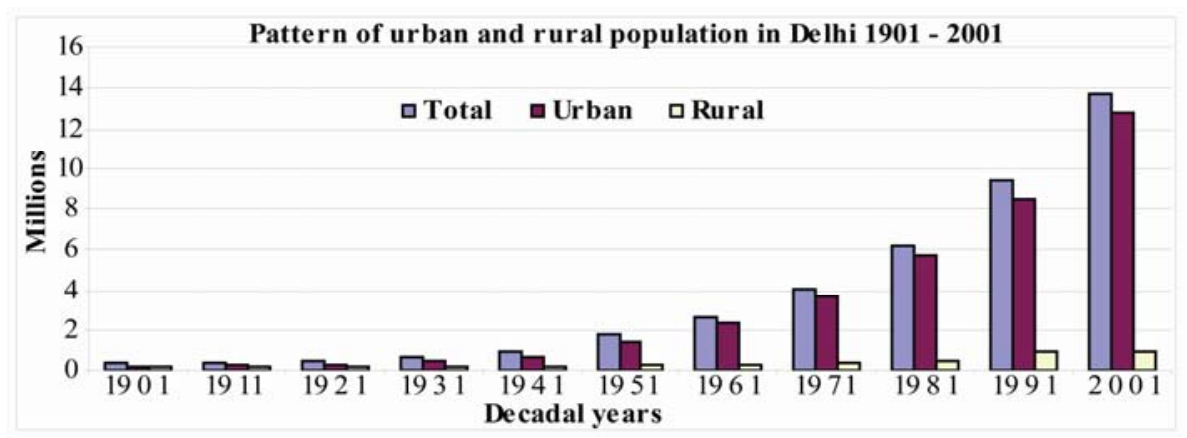

Figure 3. Population in Delhi 1901-2001.

Table 1. District-wise area and population of Delhi during 1991 to 2001.

\begin{tabular}{|c|c|c|c|c|c|c|c|c|c|}
\hline \multirow[b]{2}{*}{ District } & \multirow[b]{2}{*}{$\begin{array}{l}\text { Area } \\
\left(\mathrm{km}^{2}\right)\end{array}$} & \multirow[b]{2}{*}{$\begin{array}{c}\% \text { Area to } \\
\text { total } \\
\text { area of State }\end{array}$} & \multicolumn{3}{|c|}{1991} & \multicolumn{3}{|c|}{2001} & \multirow[b]{2}{*}{$\begin{array}{c}\text { Decadal } \\
\text { growth } \\
1991-2001\end{array}$} \\
\hline & & & $\begin{array}{c}\text { Population } \\
\text { (In lakhs) }\end{array}$ & $\begin{array}{l}\text { \% to Pop- } \\
\text { ulation } \\
\text { of State }\end{array}$ & $\begin{array}{c}\text { Density } \\
\text { (pers./km²) }\end{array}$ & $\begin{array}{c}\text { Population } \\
\text { (In lakhs) }\end{array}$ & $\begin{array}{l}\text { \% to Pop } \\
\text { ulation } \\
\text { of State }\end{array}$ & $\begin{array}{c}\text { Density } \\
\text { (pers./km²) }\end{array}$ & \\
\hline North-West & 440 & 29.7 & 1,778,268 & 18.88 & 18,088 & 2,847,395 & 20.66 & 29,395 & 60.12 \\
\hline South & 250 & 16.9 & $1,502,878$ & 15.95 & 26,261 & $2,258,367$ & 16.38 & 25,760 & 50.27 \\
\hline West & 129 & 8.7 & $1,434,008$ & 15.22 & 15,986 & $2,119,641$ & 15.38 & 22,637 & 47.81 \\
\hline North-East & 60 & 4.05 & $1,085,250$ & 11.52 & 11,116 & $1,763,712$ & 12.8 & 16,431 & 62.52 \\
\hline South-West & 420 & 28.3 & 1,084,705 & 11.51 & 11,471 & $1,749,492$ & 12.69 & 12,996 & 61.29 \\
\hline East & 64 & 4.31 & $1,023,078$ & 10.86 & 6,012 & $1,448,770$ & 10.51 & 9,033 & 41.61 \\
\hline North & 60 & 4.05 & 688,252 & 7.31 & 4,042 & 779,788 & 5.66 & 6,471 & 13.30 \\
\hline Central & 25 & 1.68 & 656,533 & 6.97 & 4,791 & 644,005 & 4.67 & 4,909 & -1.91 \\
\hline New Delhi & 35 & 2.36 & 167,672 & 1.78 & 2,583 & 171,806 & 1.25 & 4,165 & 2.47 \\
\hline Total NCT Delhi & 1483 & 100.00 & $94,20,644$ & 100.00 & 6352 & $137,82,976$ & 100.00 & 9,294 & 46.31 \\
\hline
\end{tabular}

Source: Census of India 1991 \& 2001

Table 2. Urban and rural population in Delhi 1901-2001.

\begin{tabular}{|c|c|c|c|c|c|c|}
\hline $\begin{array}{l}\text { Census } \\
\text { Years }\end{array}$ & $\begin{array}{c}\text { Total } \\
\text { Population }\end{array}$ & $\begin{array}{l}\text { Total Urban } \\
\text { Population }\end{array}$ & $\begin{array}{l}\text { \% of Urban } \\
\text { Population }\end{array}$ & $\begin{array}{l}\text { \% of Rural } \\
\text { Population }\end{array}$ & $\begin{array}{c}\text { Annual exponen- } \\
\text { tial } \\
\text { growth rate }\end{array}$ & $\begin{array}{c}\text { Decennial } \\
\text { growth percent }\end{array}$ \\
\hline 1901 & $4,05,819$ & $2,14,115$ & 52.76 & 47.34 & -- & - \\
\hline 1911 & $4,13,851$ & $2,37,944$ & 57.50 & 42.5 & 1.1 & 11.13 \\
\hline 1921 & $4,88,452$ & $3,04,420$ & 62.32 & 37.68 & 2.5 & 27.94 \\
\hline 1931 & $6,36,246$ & $4,47,442$ & 70.33 & 29.67 & 3.9 & 46.98 \\
\hline 1941 & 9,17,939 & $6,95,686$ & 75.79 & 24.21 & 4.4 & 55.48 \\
\hline 1951 & $17,44,072$ & $14,37,134$ & 82.40 & 17.60 & 7.3 & 106.58 \\
\hline 1961 & $26,58,612$ & $23,59,408$ & 88.75 & 11.25 & 5.0 & 64.17 \\
\hline 1971 & $40,65,698$ & $36,47,023$ & 89.68 & 10.32 & 4.4 & 54.57 \\
\hline 1981 & $62,20,406$ & $57,68,200$ & 92.73 & 7.27 & 4.6 & 58.16 \\
\hline 1991 & $94,20,644$ & $84,71,625$ & 89.93 & 10.07 & 3.8 & 46.87 \\
\hline 2001 & $137,82,976$ & $12,81,9761$ & 93.01 & 6.99 & 4.1 & 51.33 \\
\hline
\end{tabular}

Census of India 1901-2001 
areas/Walled City and Rural villages are the various types of settlements which are commonly seen in Delhi.

\section{Data and Methodology}

District map showing the villages, Census towns, Municipal areas and wards of Delhi has been used for preparation of base map. Guide map and East Delhi map was geo-referenced with the help of 1976 Survey of India (SoI) topographical sheet no. $53 \mathrm{H} / 6 \mathrm{NW}$ and $53 \mathrm{H} / 6$ SW at the scale of 1:25,000 and Guide map of Delhi 1982. The Advanced Space-born Thermal Emission Reflection Radiometer (ASTER) data acquired on $22^{\text {nd }}$ Nov. 2003 has been used in this study. The ASTER satellite image has $15 \mathrm{~m}$ ground resolution, which has been used for generate land use/land cover map of 2003 and from that map built-up area was extracted. Guide map of Delhi 1982 was digitised, cleaned, topology was built to prepare land use/land cover map in Arc GIS 9.0 software Figure 4.

The satellite data was enhanced before classification using histogram equalization in ERDAS Imagine 8.7 for the better quality of the image and to achieve better classification accuracy. Further both satellite data and Guide map which was used as base map were re-projected to a common Universal Traverse Mercator (UTM) projection/coordinate system on 1:50,000 scale. The data were resampled to a common spatial resolution of $15 \mathrm{~m}$. Then supervised classification was performed using maximum likelihood algorithm for ASTER data with 4 bands in VNIR range, i.e., band $1(0.52-0.60 \mu \mathrm{m})$, band 2 (0.63$0.69 \mu \mathrm{m})$, band $3(0.76-0.86 \mu \mathrm{m})$, band 4 near infrared $(0.76 .90 \mu \mathrm{m})$. Two land use land cover map was prepare 1) using Guide map of 1982 2) using ASTER satellite data of 2003. Thereafter from these two maps built-up area, open spaces which also includes open green spaces were extracted for analysis. Digitized administrative boundary was superimposed on the classified land use/ land cover map in order to get ward-wise information of both the years 1982 and 2003.

The demographic data (household density, occupancy ratio and population density) have been collected from the office of Register General of India, New Delhi. The data related to the environmental pollution has been collected from the Central Pollution Control Board (CPCB), New Delhi. Integration of spatial and non-spatial (attribute data), which are collected from secondary sources i.e. pollution, population, etc. were done in GIS environment using Arc GIS 9.0. To asses the quality of urban environment 8 parameters 1) \% age of built-up area 2) open spaces 3) household density 4) occupancy ratio 5) population density 6) accessibility to roads 7) noise pollution 8) foul smell were selected, which were assigned weigh- tages according to their relative importance Table 3. All parameters are taken into consideration for 2003 but two parameters housing density and occupation ratio have not used in 1982 due to not availability of data. Weighted Overlay Technique was applied for assessing and evaluating the quality of the urban environment. Quantitative weights were given to all parameters according to their relative importance for the assessment of quality of urban environment.

On the basis of importance the score for the parameters I, II, III, IV, and V are multiplied by 3 before adding with the parameters VI, VII and VIII for the year 2003, while for year 1982 the sum of selected parameter I, II and $\mathrm{V}$ were multiplied by 5 instead of 3 before adding to the VI, VII and VIII parameters. This is done for making comparability in the two years in terms of their values assigned, because in 1982 the parameters III \& IV, i.e., housing density and occupancy ratio have not been used due to non availability of data. The weighted layers were clubbed by using the composite score and based on it the final layer of quality of environment map for East Delhi was prepared. To assess the change in environment quality the composite scores of 2003 has been subtracted from the composite scores of 1982. Finally the resulting composite scores have been categorized into 7 different classes.

\section{Result and Discussions}

\subsection{Built up Area}

Built up area is directly related to the housing density, higher the housing density the lower the environmental quality [5]. As a result of built-up densities, hazards such as noise and air pollution are likely to increase, since many of these problems are caused by transportation. Higher urban densities are also liable to damage open spaces within the cities, as well as the quality of life in over-crowded residential neighbourhoods [16]. The East Delhi district was sparsely built 10 years before but now many new multi-storeyed residential colonies have come up. In 1982, the built-up area varies from $40 \%$ to $60 \%$ in north-eastern part and negligible in other parts. The ward no. 78 Jagatpuri ranked first in terms of percentage of built up area $80.16 \%$. Lowest built up area is in Gharoli village, which is a town in 2001 Census, with $2.8 \%$. In 2003, the built-up areas have been increased and Jagatpuri ranked first with $94 \%$ in 1982 it was $80.16 \%$. The village Chilla Saroda Khadar has least built up area of only $8.65 \%$ which is in first category. There were 11 villages, Census towns which had built-up area of $<20 \%$ in 1982 but in 2003 only one left in $<20 \%$ category other have gone to more built-up category. Surprisingly the 
Table 3. Parameters of urban environmental quality.

\begin{tabular}{|c|c|c|c|c|c|}
\hline S No. & Parameters & Class/Category & \multicolumn{2}{|c|}{ Weightages } & Data source \\
\hline \multirow{5}{*}{$\mathrm{I}$} & \multirow{5}{*}{ Built up area } & Below 20 \% & \multicolumn{2}{|c|}{5} & \\
\hline & & $20 \%-40 \%$ & \multicolumn{2}{|c|}{4} & \\
\hline & & $40 \%-60 \%$ & \multicolumn{2}{|c|}{3} & $\begin{array}{l}\text { Extracted from guide map, } 1982 \text { and } \\
\text { ASTER image, } 2003\end{array}$ \\
\hline & & $60 \%-80 \%$ & \multicolumn{2}{|c|}{2} & \\
\hline & & Above $80 \%$ & \multicolumn{2}{|c|}{1} & \\
\hline \multirow{5}{*}{ II } & \multirow{5}{*}{ Open spaces } & Below $10 \%$ & \multicolumn{2}{|c|}{1} & \\
\hline & & $10 \%-30 \%$ & \multicolumn{2}{|c|}{2} & \\
\hline & & $30 \%-50 \%$ & \multicolumn{2}{|c|}{3} & $\begin{array}{l}\text { It is clipped from guide map, } 1982 \text { and } \\
\text { ASTER image, } 2003\end{array}$ \\
\hline & & $50 \%-70 \%$ & \multicolumn{2}{|c|}{4} & \\
\hline & & Above $70 \%$ & \multicolumn{2}{|c|}{5} & \\
\hline \multirow{5}{*}{ III } & \multirow{5}{*}{ Household density } & Below 50 & \multicolumn{2}{|c|}{5} & \\
\hline & & $50-100$ & \multicolumn{2}{|c|}{4} & \\
\hline & & $100-150$ & \multicolumn{2}{|c|}{3} & $\begin{array}{l}\text { It is collected from Primary Census } \\
\text { Abstract (PCA), } 2003\end{array}$ \\
\hline & & $150-200$ & \multicolumn{2}{|c|}{2} & \\
\hline & & Above 200 & \multicolumn{2}{|c|}{1} & \\
\hline \multirow{4}{*}{ IV } & \multirow{4}{*}{$\begin{array}{l}\text { Occupancy } \\
\text { ratio }\end{array}$} & Below $4.5 \mathrm{p} / \mathrm{h}$ & & & \\
\hline & & $4.5-5.0 \mathrm{p} / \mathrm{h}$ & & & It is collected from PCA 2003 \\
\hline & & $5.0-5.5 \mathrm{p} / \mathrm{h}$ & & & it is conlected Honl PLA, zU03 \\
\hline & & Above $5.5 \mathrm{p} / \mathrm{h}$ & & & \\
\hline & & Below 300 p/km² & & & \\
\hline & & $300-500$ p/km² & & & \\
\hline $\mathrm{V}$ & Population density & $500-700 \mathrm{p} / \mathrm{km}^{2}$ & & & $\begin{array}{l}\text { It is assessed by projected population for } \\
1982 \& 2003 \text { and the built-up area. }\end{array}$ \\
\hline $\mathrm{V}$ & & $700-1000 \mathrm{p} / \mathrm{km}^{2}$ & & & \\
\hline & & Above 1000 & & & \\
\hline & Buffer zones & & Zone I(A) & Zone II(B) & \\
\hline & & & $250 \mathrm{~m}$ & $500 \mathrm{~m}$ & \\
\hline & & No accessibility & 4 & 1 & \\
\hline & $\%$ age of & $1 \%-25 \%$ & 8 & 2 & $\begin{array}{l}\text { The major roads are mapped and their } \\
\text { buffer has been created at the distance of }\end{array}$ \\
\hline VI & population accessible & $25 \%-50 \%$ & 12 & 3 & $250 \mathrm{~m}$ and $500 \mathrm{~m}$ in Arc GIS, which was \\
\hline & to roads & $50 \%-75 \%$ & 16 & 4 & $\begin{array}{l}\text { overlaid on the built-up layer to get ace- } \\
\text { ssible areas. }\end{array}$ \\
\hline & & $75 \%-99 \%$ & 20 & 5 & \\
\hline & & $100 \%$ & 24 & 6 & \\
\hline & & & $40 \mathrm{~m}$ & $180 \mathrm{~m}$ & \\
\hline & & Not affected & 10 & 5 & The buffer of $40 \mathrm{~m}$ and 180 \\
\hline VII & $\%$ age of & $1 \%-5 \%$ & 8 & 4 & exposure zone) has been created for the \\
\hline VII & $\begin{array}{l}\text { from noise } \\
\text { from }\end{array}$ & $5 \%-15 \%$ & 6 & 3 & two tracks of Eastern Railway and over- \\
\hline & & $15 \%-30 \%$ & 4 & 2 & \\
\hline & & Above 30\% & 2 & 1 & \\
\hline & & & $250 \mathrm{~m}$ & $500 \mathrm{~m}$ & \\
\hline & & Not affected & 10 & 5 & \\
\hline VIII & \% age of & $1 \%-15 \%$ & 8 & 4 & $\begin{array}{l}\text { The open chocked drains have been } \\
\text { digitised in GIS and the smell affected }\end{array}$ \\
\hline VIII & from foul smell & $15 \%-30 \%$ & 6 & 3 & areas has been determined by making \\
\hline & & $30 \%-45 \%$ & 4 & 2 & \\
\hline & & Above $45 \%$ & 2 & 1 & \\
\hline
\end{tabular}




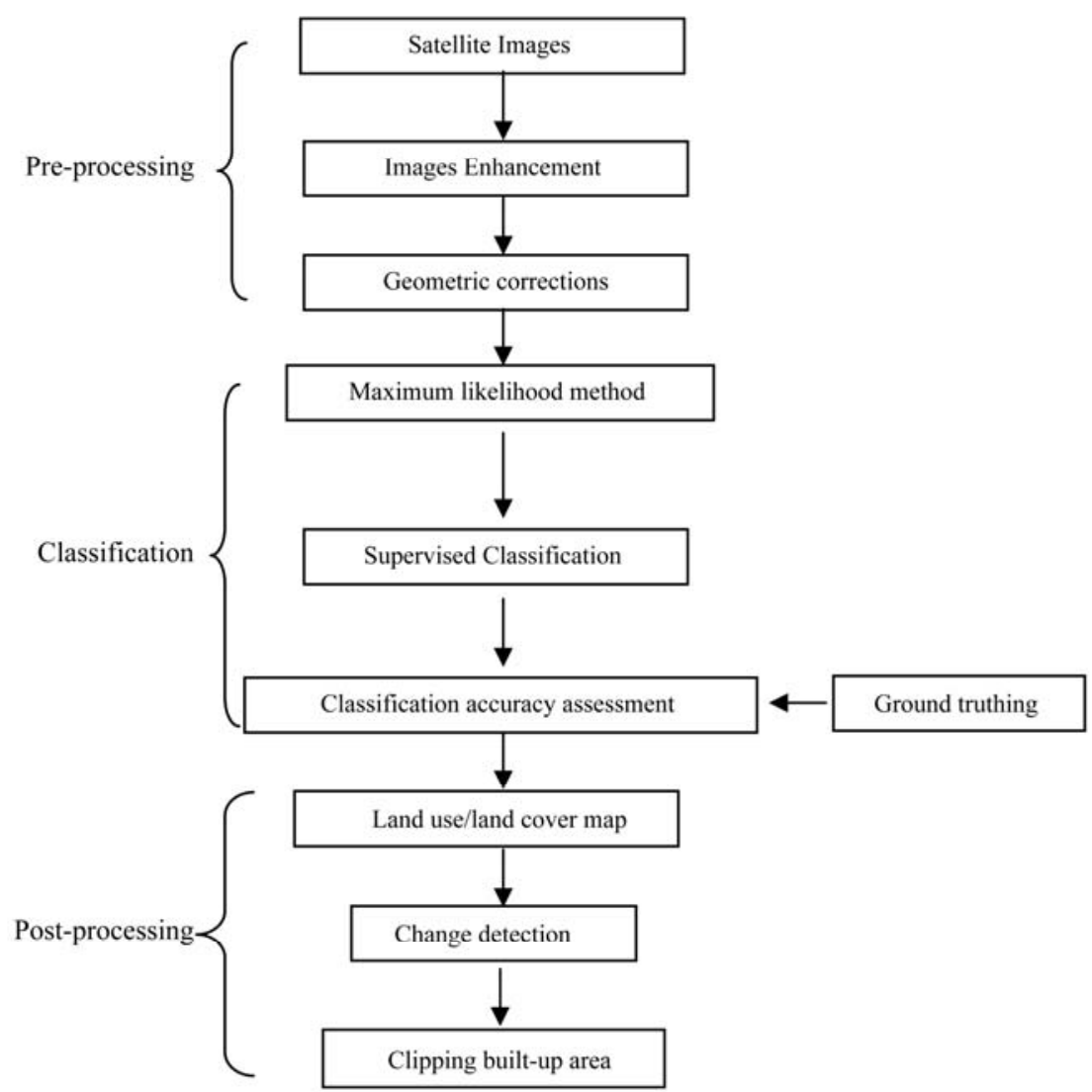

Figure 4. Flow chart of methodology for land use/land cover classification.

Patparganj, a higher-medium income colony, which also had built-up area of $<20 \%$ have moved to $60-80 \%$ category in 2003 (Table 4 \& Figure 5). This shows that in most of the wards and villages land use have been changed by man. That is why the built up areas have increased in most of the areas.

\subsection{Open Spaces}

The open space is another important aspect for the assessment of environmental quality which provides pollution free environment for the people living nearby. Vegetated and open green spaces (parks) have been taken as one of the most important parameter of quality of urban environment assessment. More open and green spaces in the city better is the quality of environment. It is very essential to have open green in the surrounding of living area for healthy life. It is commonly seen that in recent years apart from few planned residential colonies other building are coming up at a very fast rate without leaving any open space or parks. In 1982 almost $2 / 3^{\text {rd }}$ of the total study area had $>70 \%$ open spaces but situation has change the other way round and after 20 years in 2003 about $90 \%$ of the area was in the $10-50 \%$ open spaces (Table 5 \& Figure 6). The ward Jagatpuri ranked last in terms of percentage of open spaces to the total area, with $17.64 \%$. The village Gharoli, which becomes as Census town in 2001 has highest 95.23\% open spaces, followed by Dallopura and Chilla Saroda Khadar. In 2003, village Chilla Saroda Khadar ranked first in terms of largest area under open spaces with $81.42 \%$ and the second is Shamas Pur, which has $72.19 \%$ open spaces. The DMC wards have less open spaces, i.e., Shaikarpur, and Jagatpuri have $2.66 \%$ and $3.7 \%$ open spaces respectively. The major changes have been observed in the all Census towns that the open spaces decreased rapidly in the past years due to expansion of residential areas. The Census town Gharoli, situated at the south-eastern boundary of East Delhi has largest area under open spaces with 58\% among all Census towns, while Patparganj has least open spaces with $28 \%$. So the DMC wards are mostly very much congested, especially the northern part of the study area.

\subsection{Housing Density}

Housing density (number of houses/ $\mathrm{Km}^{2}$ ) shows the pressure of households on existing utilities and services 


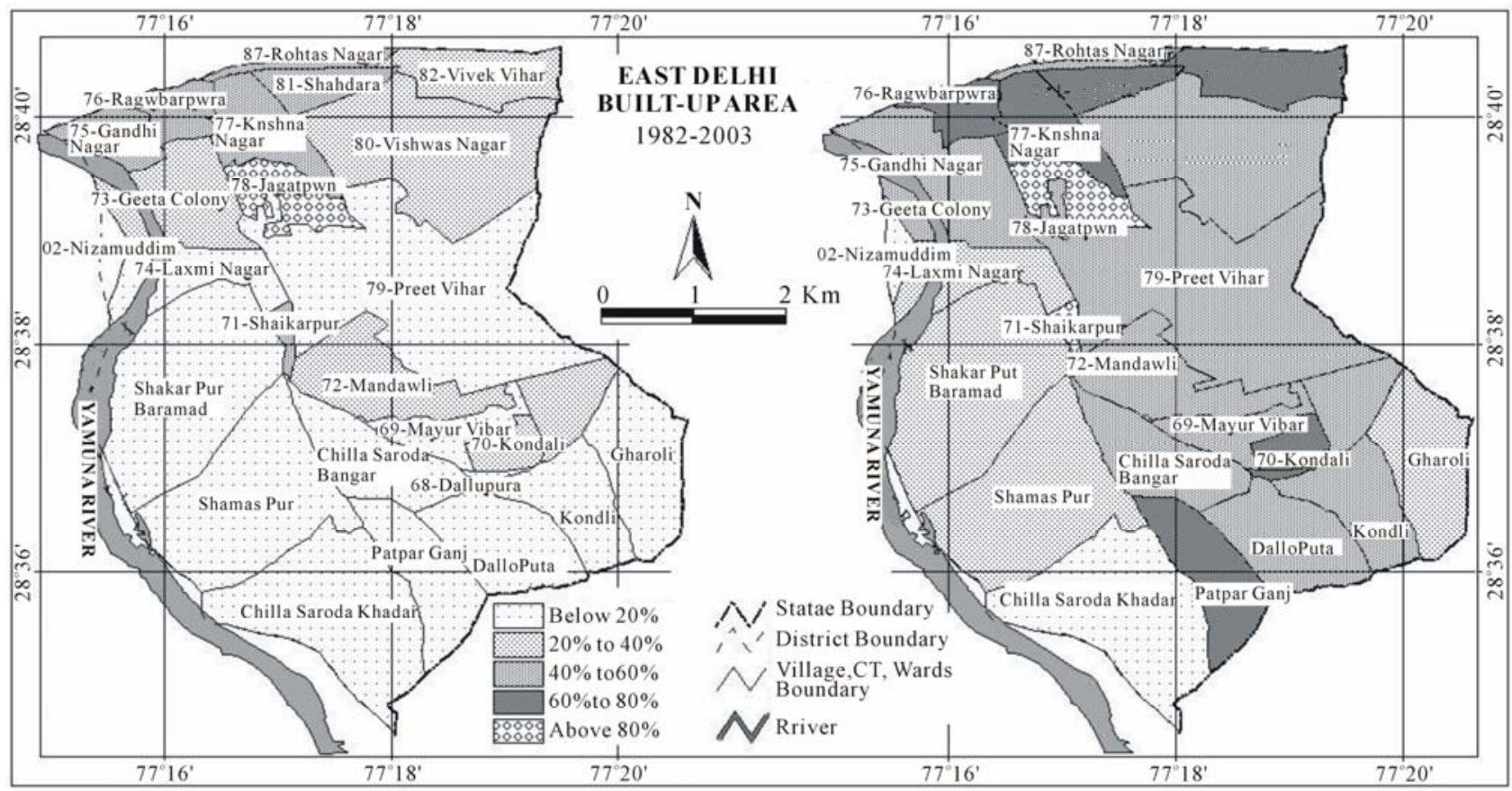

Figure 5. Change in built up area in east Delhi, 1982-2003.

Table 4. Built up areas in different wards, CTs \& villages in 1982 \& 2003.

\begin{tabular}{lcc}
\hline Wards, Census Towns and Villages & & Built up (\%) weights \\
\hline 1982 & 2003 & \\
\hline
\end{tabular}

Chilla S. Khadar(Vill), Gharoli(Vill), Dallo Pura(Vill), Kondli(Vill), Chilla S Bangar(Vill), Patparganj(Vill), Shamas Pur(Vill), 69-Mayur Vihar, 68-Dallopura, 79-Preet Vihar, 74-Laxmi Nagar, Shakar Pur(Vill)
Chilla S. Khadar(Vill) Shamas Pur(Vill), Shakar Pur(Vill), 74-Laxmi Nagar, Gharoli(CT)

73-Geeta Colony, Kondli(CT), Chilla S Bangar(CT), 75-Gandhi Nagar, 87-Rohtas Nagar, 79-Preet Vihar, Dallo Pura(CT), 69-Mayur Vihar, 72-Mandawli, 80-Vishwas Nagar

82-Vivek Vihar, Patparganj(CT), 68-Dallopura, 81-Shahdara, 77-Krishna Nagar, 70-Kondali, $\quad 60 \%-80 \% \quad 2$ 76-Raghubarpura

71-Shaikarpur, 78-Jagatpuri

$$
<20 \%
$$

$20 \%-40 \%$

$$
40 \%-60 \% \quad 3
$$

$>80 \%$

1 (15ar, 75-Gandhi Nagar, 71-Shaikarpur -Raghubarpura, 77-Krishna Nagar, 81-Shahdara

None

78-Jagatpuri

Note: Vill - Villages, CT - Census towns

i.e., drinking water and sanitation etc. which is needed by the people. Higher the housing density, poorer the quality of urban environment [5]. In 2003, the Delhi Municipal Corporation (DMC) Raghubarpura ward had highest housing density with 32,700 houses $/ \mathrm{km}^{2}$. The highest housing density among Census towns is in Gharoli with 20,000 houses $/ \mathrm{km}^{2}$. The lowest housing density is in
Samaspur village. The village Chilla Saroda Khadar has high housing density among all villages with 108 houses/ $\mathrm{km}^{2}$. It can be easily observed that a large area in the middle of the district, i.e., Mandawli, Preet Vihar, Shaikarpur and villages Shakar Pur Barmad and Shamaspur has less than 5,000 houses $/ \mathrm{km}^{2}$ housing density (Table 6 \& Figure 7). While in northward and southward 


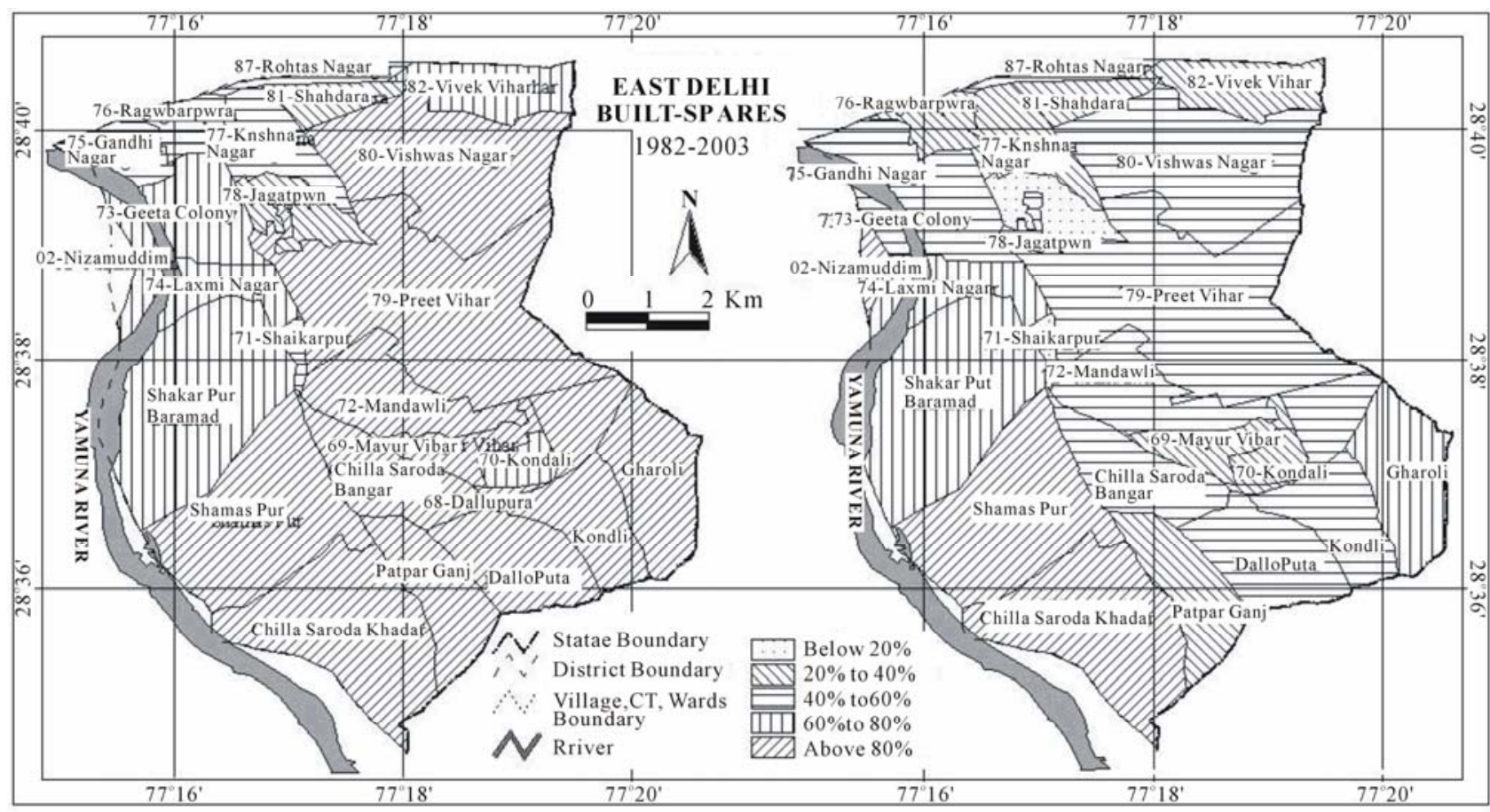

Figure 6. Percentage open spaces in east delhi, 1982 \& 2003.

Table 5. Open spaces in different wards, CTs and villages in 1982 \& 2003.

\begin{tabular}{|c|c|c|c|}
\hline \multicolumn{2}{|c|}{ Wards, Census Towns and Villages } & \multirow{2}{*}{ Open Spaces } & \multirow{2}{*}{ weight } \\
\hline 1982 & 2003 & & \\
\hline None & 71-Shaikarpur, 78-Jagatpuri & Below 10\% & 1 \\
\hline 78-Jagatpuri, 81-Shahdara & $\begin{array}{l}\text { 76-Raghubarpura, 70-Kondali, 77-Krishna Nagar, } \\
\text { 81-Shahdara, 68-Dallopura, 82-Vivek Vihar, Pat- } \\
\text { parganj(CT), 69-Mayur Vihar }\end{array}$ & $10 \%-30 \%$ & 2 \\
\hline $\begin{array}{l}\text { 76-Raghubarpura, 77-Krishna Nagar, 75-Gandhi } \\
\text { Nagar, 87-Rohtas Nagar, 71-Shaikarpur }\end{array}$ & $\begin{array}{l}\text { 72-Mandawli, 75-Gandhi Nagar, 87-Rohtas Nagar, } \\
\text { Dallo Pura(CT), 80-Vishwas Nagar, 79-Preet Vi- } \\
\text { har, Chilla S. Bangar(CT), 73-Geeta Colony } \\
\text { (42.76), Kondli(CT) }\end{array}$ & $30 \%-50 \%$ & 3 \\
\hline $\begin{array}{l}\text { 73-Geeta Colony, 74-Laxmi Nagar, 70-Kondali, } \\
\text { 82-Vivek Vihar, Shakar Pur Baramad(Vill) }\end{array}$ & $\begin{array}{l}\text { 74-Laxmi Nagar, Gharoli(CT), Shakar Pur } \\
\text { Baramad(Vill) }\end{array}$ & $50 \%-70 \%$ & 4 \\
\hline $\begin{array}{l}\text { 80-Vishwas Nagar, 72-Mandawli, 79-Preet Vihar, } \\
\text { 69-Mayur Vihar, Shamas Pur(Vill), }\end{array}$ & & & \\
\hline $\begin{array}{l}\text { 68-Dallopura,Patparganj(Vill), Chilla S. Ban- } \\
\text { gar(Vill), Kondli(Vill), Chilla S. Khadar(Vill), } \\
\text { Dallo Pura(Vill), Gharoli(Vill) }\end{array}$ & Shamas Pur(Vill), Chilla S. Khadar(Vill) & Above $70 \%$ & 5 \\
\hline
\end{tabular}

direction the housing density is very high, especially in the north eastern part is the old part of the East of Delhi. The southern areas are recently developed, but due to easily availability of land at cheap rates in NOIDA.

\subsection{Occupancy Ratio}

Number of persons/household which is also referred as occupancy ratio gives the picture of pressure of popula- 


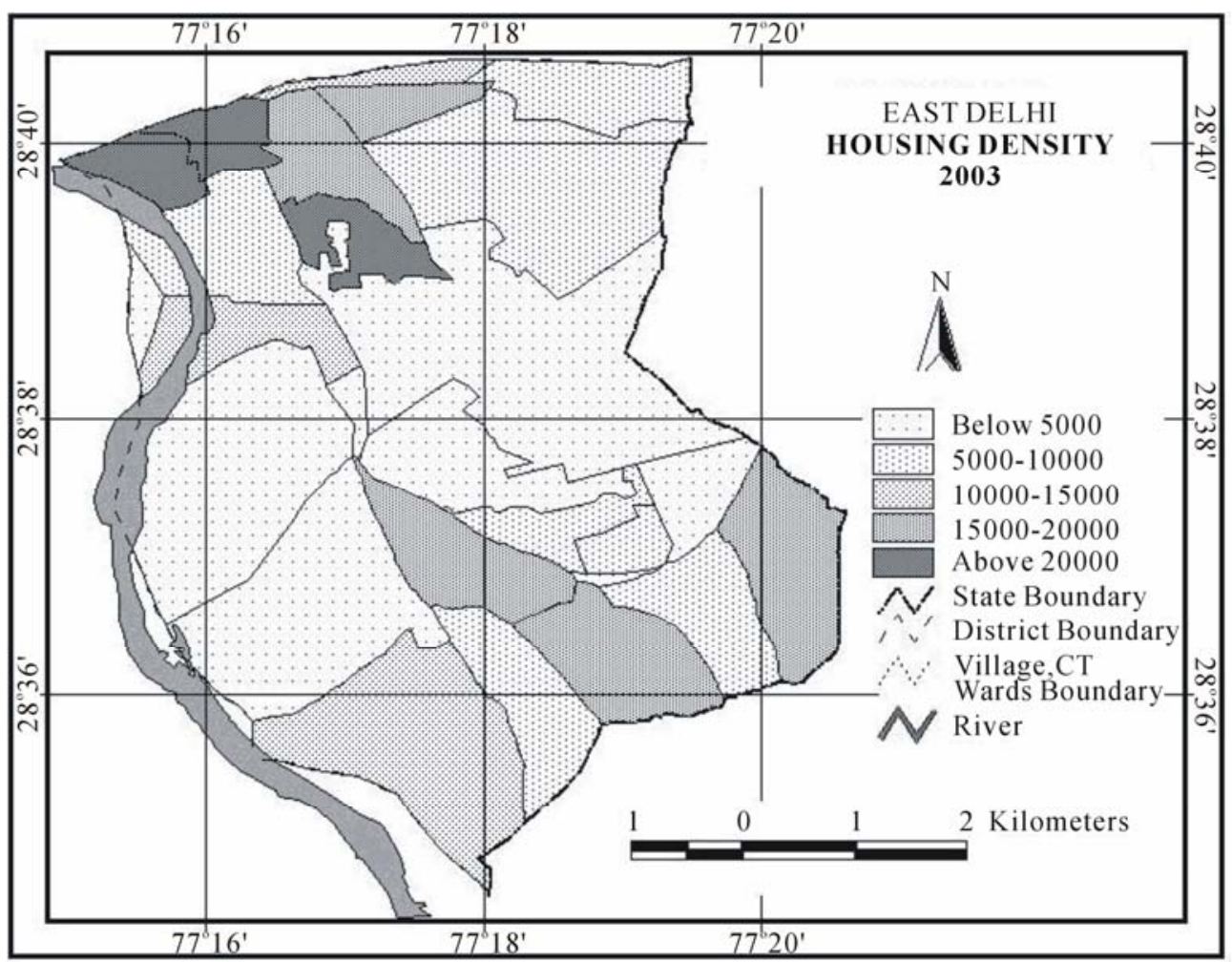

Figure 7. Household density of east delhi, 2003.

Table 6. Housing density in different wards, census towns \& villages.

\begin{tabular}{|c|c|c|}
\hline Wards, Census Towns and Villages & $\begin{array}{l}\text { Housing Density } \\
\text { (Household } / \mathrm{km}^{2} \text { ) }\end{array}$ & weights \\
\hline Shamas Pur(Vill), Shakar Pur Baramad(Vill), 71-Shaikarpur, 72-Mandawli, 79-Preet Vihar, 68-Dallopura & Below 5,000 & 5 \\
\hline Patparganj(CT), 69-Mayur Vihar, 80-Vishwas Nagar, Kondli(CT), 82-Vivek Vihar, 70-Kondali, 73-Geeta Colony & $5,000-1,0000$ & 4 \\
\hline Chilla Saroda Khadar(Vill), 87-Rohtas Nagar, 74-Laxmi Nagar & $10,000-15,000$ & 3 \\
\hline 77-Krishna Nagar, Chilla Saroda Bangar(CT), 81-Shahdara, Dallo Pura(CT), Gharoli(CT) & $15,000-20,000$ & 2 \\
\hline 78-Jagatpuri, 75-Gandhi Nagar, 76-Raghubarpura & Above 20,000 & 1 \\
\hline
\end{tabular}

tion on individual house. Lesser the occupancy ratio better will be the quality of environment. The data for 1982 was not available in the Government office so occupancy ration was analysed for 2003 only. In 2003 the all villages of the study area has low occupancy rate, while the DMC wards in the northern part has highest occupancy ratio, among them Raghubarpura, Gandhi Nagar, Rohtas Nagar and Shahdara has above 5 persons/household. Among Census towns Kondali has lowest and Dallupura has highest occupancy ratio (Table $7 \&$ Figure 8). This is because these areas are mainly inhabited by lowermedium income people who have large family size.

\subsection{Population Density}

The population grows very fast in urban areas due to migration of people mainly from rural areas and also from nearby smaller cities and towns, which in turn leads to pressure on all existing resources of bigger and metro cities like Delhi. So the population density has been considered inversely related parameters to the quality of urban environment. In 1982, entire north-eastern part had low population density and out of 25 villages 20 villages had population density of 1000 person/ $\mathrm{km}^{2}$ or even less Table 8. The Raghubarpura ward ranked first in terms of high population density with 1,524 person $/ \mathrm{km}^{2}$.

In 2003, the analysis of population density indicates that the DMC wards, which are situated along the Grand Trunk road, have very high population density except some areas. The northern and southern part of the study area is more populated than the middle part. DMC wards, Raghubarpura, Gandhi Nagar, Jagatpuri, Sahadara in 


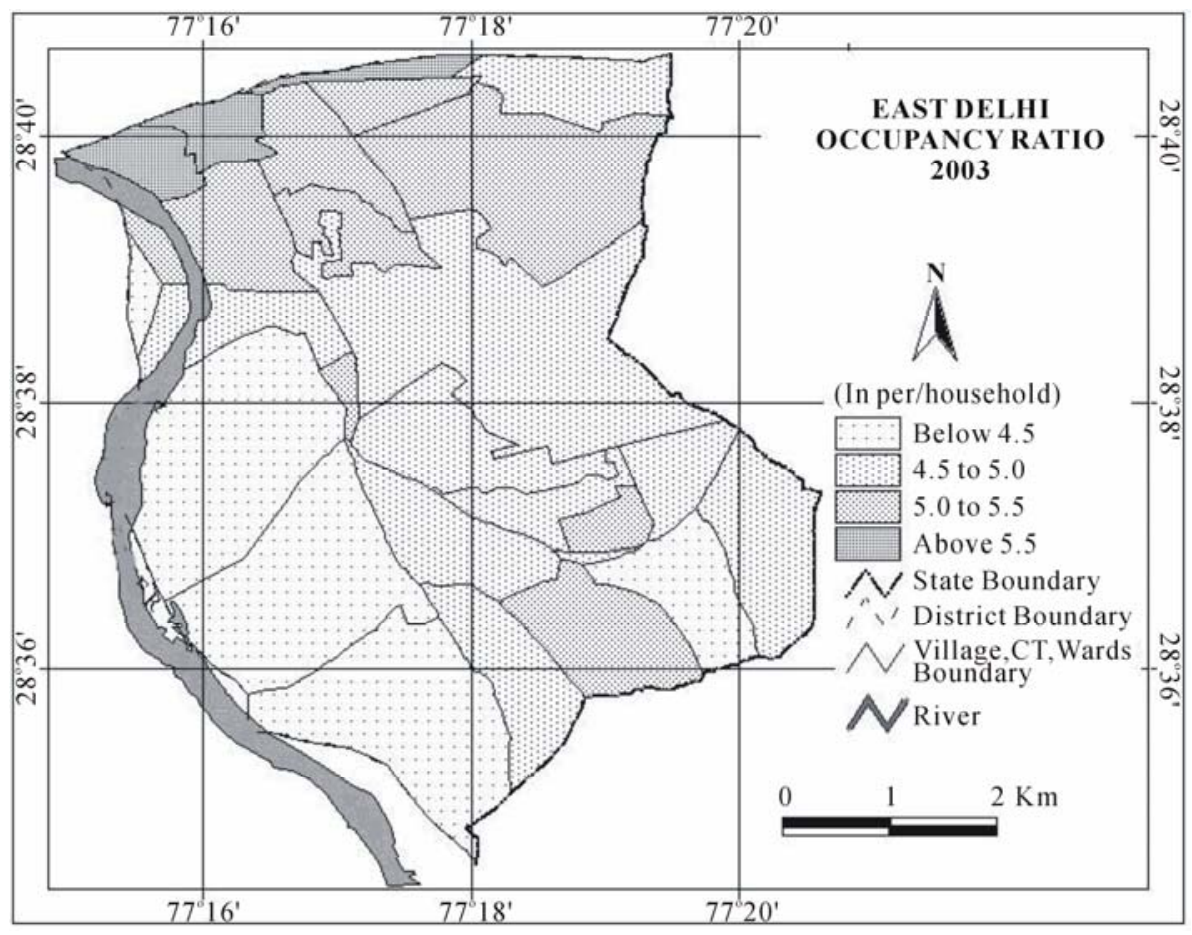

Figure 8. Occupancy ratio of east delhi, 2003.

Table 7. Occupancy ration in different wards census towns 7 villages.

\begin{tabular}{lcc}
\hline \multicolumn{1}{c}{ Wards, Census Towns and Villages } & Occupancy Ratio (persons/household) & Weight \\
\hline Chilla S. Khadar(Vill), Shakar Pur Baramad(Vill), Shamas Pur(Vill) & Below 4 \\
Kondli(CT), Chilla S. Bangar(CT), Patparganj(CT), Gharoli(CT), 69-Mayur Vihar, & $4-5$ \\
72-Mandawli, 79-Preet Vihar & \\
82-Vivek Vihar, 74-Laxmi Nagar, 68-Dallopura, 71-Shaikarpur, Dallo Pura(CT), & $5-5$ \\
78-Jagatpuri, 73-Geeta Colony, 80-Vishwas Nagar, 77-Krishna Nagar, 70-Kondali & Above 5 \\
81-Shahdara, 87-Rohtas Nagar, 75-Gandhi Nagar, 76-Raghubarpura & 1 \\
\hline
\end{tabular}

North and a Census town Dallopura have population density $>1,000$ person $/ \mathrm{km}^{2}$ (Table 8 \& Figure 9). The northern part which was developed earlier is experiencing very high population pressure due to heavy influx of migrants from Bihar and Bengal, while the southern part which is recently developed due to migration from adjoining state, like Uttar Pradesh, Haryana and Rajasthan.

\subsection{Accessibility to Roads}

Transportation affects urban quality of life because of the type of accessibility it allows. Therefore, distance of residential colonies from major roads is an important aspect with respect to availing the utility and service facilities. In this regard two buffer zones at the distance of $250 \mathrm{~m}$ and $500 \mathrm{~m}$ were created along the major roads Figure 10. The total road length available in Delhi is just $0.28 \mathrm{~km} / 000$ populations. The number of vehicles in
Delhi is rapidly increasing and is expected to reach 3.87 million by the year 2015 [17]. This leads to traffic congestion and reduced traffic speeds, often as low as $10 \mathrm{~km} / \mathrm{hrs}$.

In 1982, the entire north-eastern part has very good road network and almost $75 \%$ area were having major roads at a distance of less than $250 \mathrm{~m}$ and rest area are served by major road at the distance of $250 \mathrm{~m}$ to $500 \mathrm{~m}$. Excluding the north-eastern part of the East district all area have poor road network. The southern most part does not have any major roads at the distance of $500 \mathrm{~m}$ but it is served by the other minor roads. About 98\% population of Gharoli Census town in the south eastern part does not have access to any major roads at a distance of $500 \mathrm{~m}$.

\subsection{Noise Affected Area}

Noise pollution is one of the most prominent and influ- 


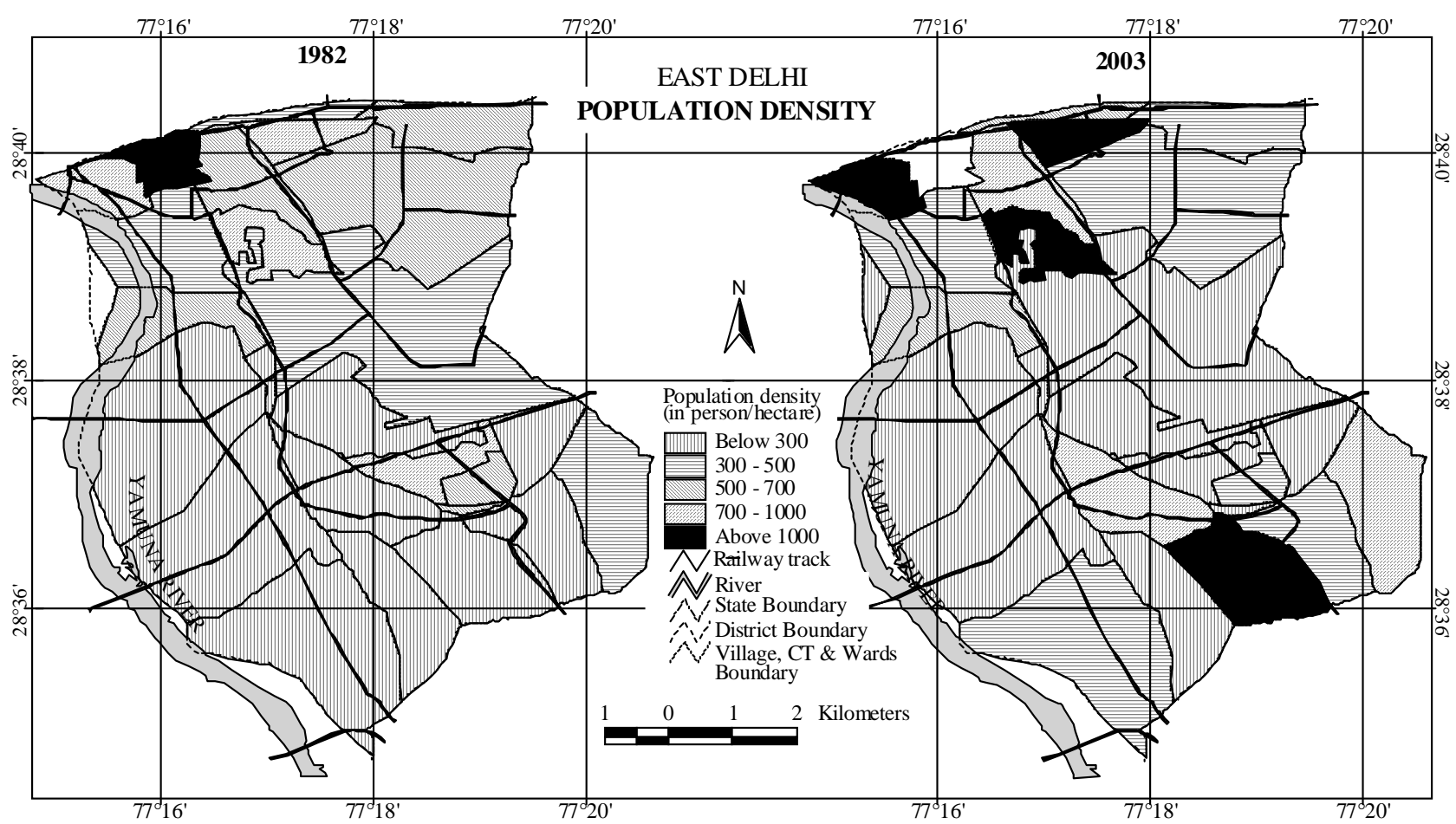

Figure 9. Population density in east delhi, 1982 \& 2003.

Table 8. Population density in different wards, CTs \& villages in 1982 \& 2003.

\begin{tabular}{llll}
\hline & Wards, Census Towns and Villages & & $\begin{array}{l}\text { Pop. Density } \\
(\text { person/km²) }\end{array}$ \\
\hline 1982 & & 2003 & weights \\
\hline
\end{tabular}

Chilla S. Khadar (Vill), Shakar Pur(Vill), Shamas Pur(Vill), Shamas Pur(Vill), Shakar Pur(Vill), 71-Shaikarpur, Patparganj(Vill), Chilla S. Bangar(Vill), 71-Shaikarpur, Dallo Pura(Vill), 72-Mandawli, Kondli(Vill) 72-Mandawli, 79-Preet Vihar, 68-Dallopura, Patparganj(CT), 69-Mayur Vihar

Gharoli(Vill), 73-Geeta Colony, 79-Preet Vihar, 87-Rohtas Kondli(CT), 80-Vishwas Nagar, 82-Vivek Vihar, Chilla S. Nagar

82-Vivek Vihar, 70-Kondali, 74-Laxmi Nagar, 80-Vishwas Nagar, 68-Dallopura, 77-Krishna Nagar

78-Jag
Vihar

76-Raghubarpura
87-Rohtas Nagar, 74-Laxmi Nagar

Chilla S. Bangar(CT), 77-Krishna Nagar, Gharoli(CT)

Khadar(Vill), 70-Kondali, 73-Geeta Colony

Dallo Pura(CT), 81-Shahdara, 78-Jagatpuri, 75-Gandhi Nagar, 76-Raghubarpura
$300-500 \quad 4$

$500-700 \quad 3$

$700-1000 \quad 2$

Above $1000 \quad 1$ ential factors affecting the quality of life of city residents and urban environmental quality [18]. Unwanted sound or noise damages human hearing and creates other related problems. Railway is considered to be one of the chief noise polluting agents. Two buffer zones at the distance of $40 \mathrm{~m}$ and $180 \mathrm{~m}$ has been created and coded with VII A and VII B respectively based on US System of Noise Exposure Forecast. Two railway tracks crosses the study area from east to west direction, one at the north while other in middle part. The first railway track affects more people while second one affects fewer, because northern part is more populated then central area Figure 11.

\subsection{Smell Affected Area}

Urban areas, especially in developing countries like India waste water is drained out from various sources like 


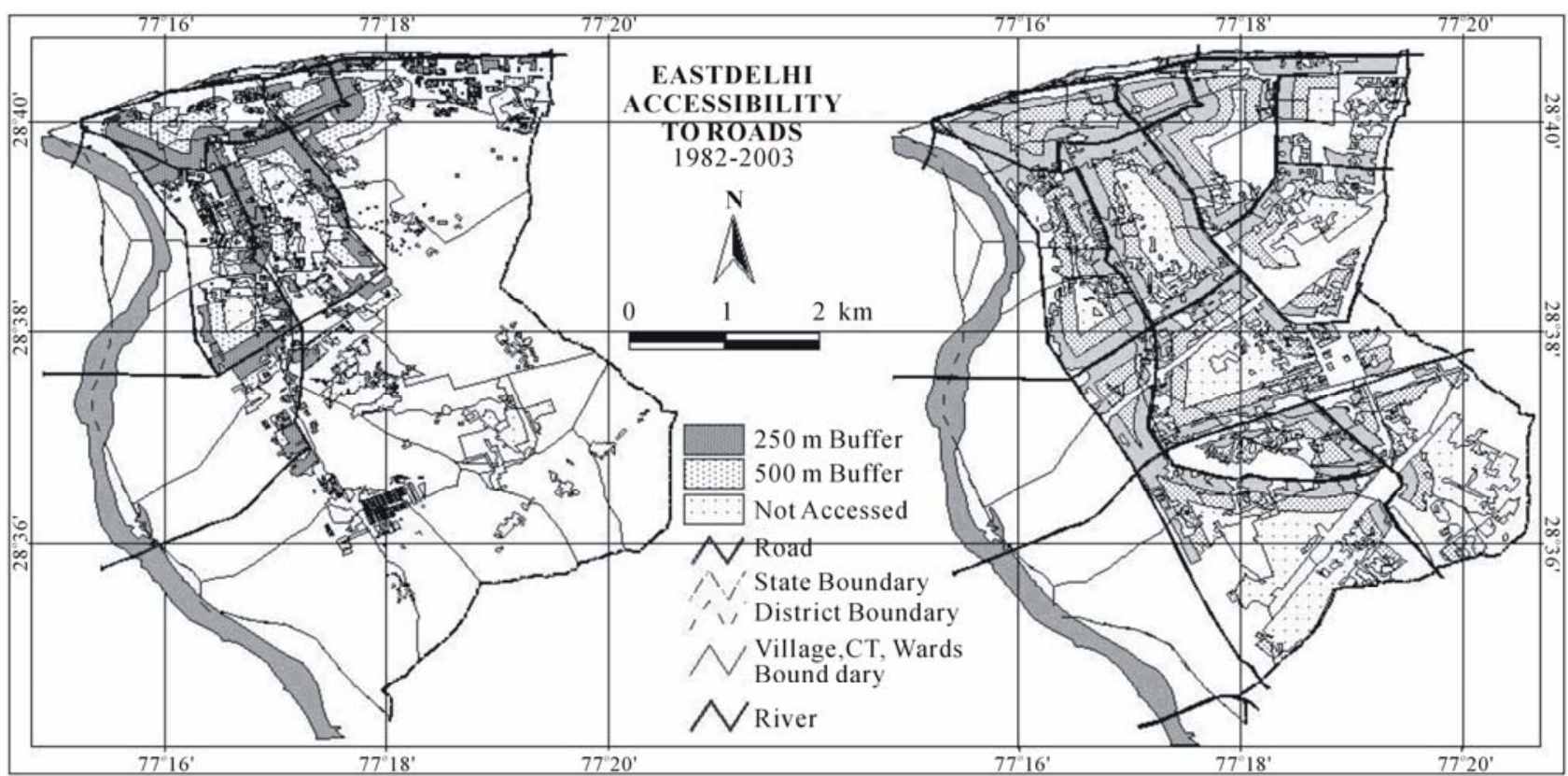

Figure 10. Major roads and accessible areas, 1982 \& 2003.

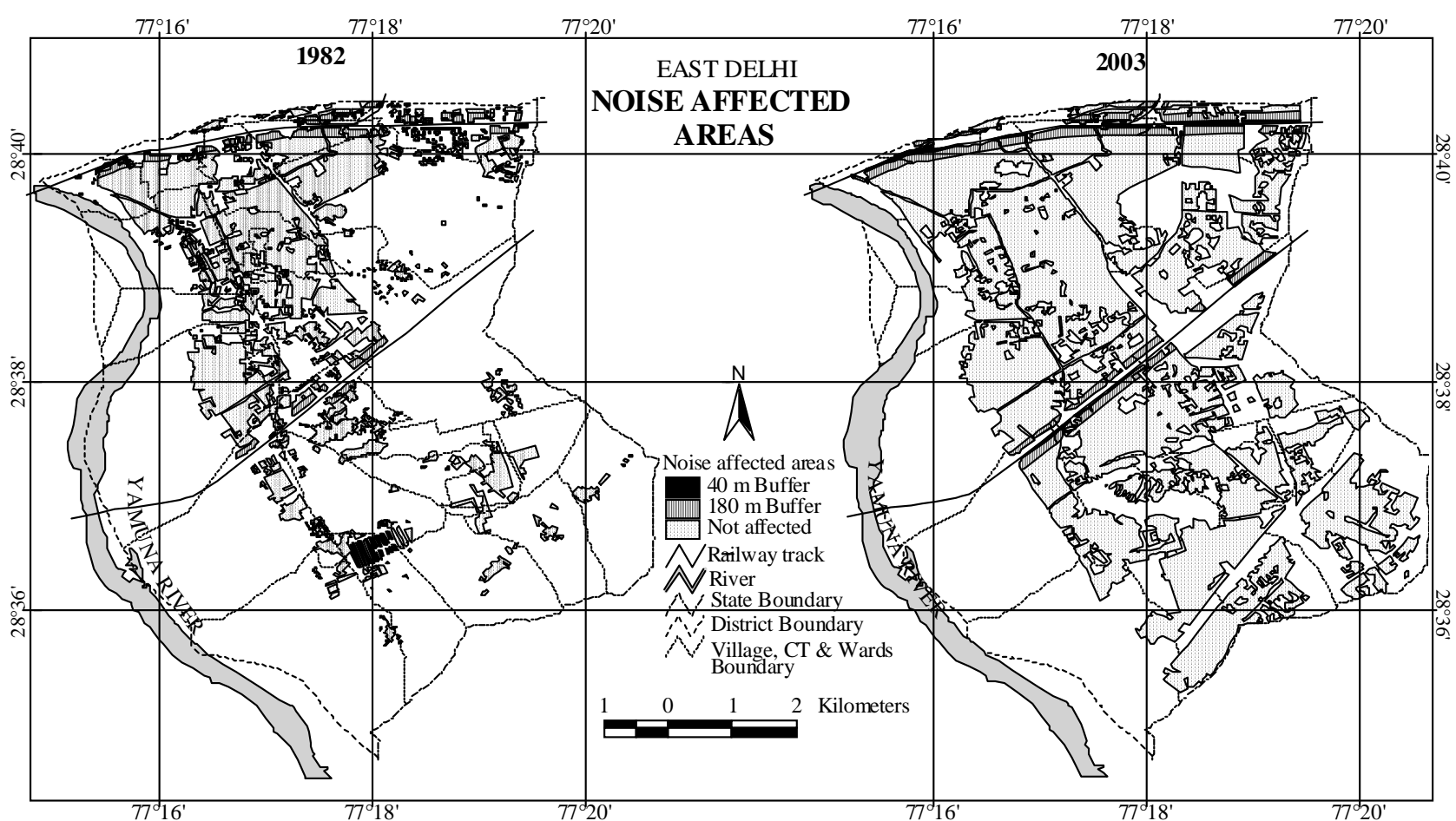

Figure 11. Noise affected areas, 1982 \& 2003.

houses, commercial places and industrial areas etc. by narrow open drains to main drainage system which is also open. Garbage is normally dumped in residential colonies wherever open space is available in the absence of garbage bins. To assess the population affected by foul smell from open drains and waste disposal sites again two buffer zones at the distance of $250 \mathrm{~m}$ and 500 $\mathrm{m}$ has been created and has been coded as VIII A and VIII B respectively.

Gahzipur drain and Shahdara drain are the two main drains in the study area both are open, while Hindon cut is the third which is very much polluted. Hindon cut 
flows from east to west direction and meet the river Yamuna, the two small drains flows from north to south meets Gahzipur drain, which flows along the Hindon cut. Shahdara drain start from middle of the study area and flows in south direction and meet at Gahzipur drain. In order to assess the population affected by foul smell due to open drainage and garbage buffer maps along drains and around garbage collection points was created to know the extent of smell. These two maps were then overlaid on the population density maps to get the idea that how many people are being affected with the foul smell due to open drainage.

The study shows that in 1982 about 86,718 persons were affected by foul smell who were living in $250 \mathrm{~m}$ buffer distance to the drain, while 1, 14,543 people are under $500 \mathrm{~m}$ foul smell buffer zone. Village Kondali is highly affected by smell i.e. $62.5 \%$ population affected by the smell in $250 \mathrm{~m}$ buffer while rest population affected by $500 \mathrm{~m}$ smell zone. In 2003 a garbage dumping site comes up at Gajipur in the south eastern part. And about 15, 00,798 persons are affected by the foul smell and out of that 5, 15,860 persons were affected by severe foul smell who lived in $250 \mathrm{~m}$ buffer distance from the drain (Figure 12). While 9, 84,938 persons comes under $500 \mathrm{~m}$ smell zone. DMC ward Krishna Nagar is highly affected by foul smell, about 52\% population are affected by the smell in $250 \mathrm{~m}$ buffer while $25 \%$ population are affected by $500 \mathrm{~m}$ smell zone.

\section{Comparative Analysis of Quality of Urban Environment (1982-2003)}

Human beings impose changes on natural ecosystems and increasing control of environment often creates conflicts between his goals and natural process. Urban concentrations intensity, the shortage of housing, transport capacity and other urban amenities affects in day-to-day life of common people. The deficiencies magnify crowding, noise, air pollutants and street filth. These factors are detrimental to health and well being of the people. Qualitative weights were assigned to 8 selected environment parameters and then composite weights were calculated for both 1982 and 2003 that shows the quality of urban environment (Tables 9 and 10). These values are classified in seven different classes of urban environment condition, i.e., excellent, very good, fair, desirable, acceptable minimum, poor, bad alarming and then maps were prepared for both the years 1982 \& 2003 (Figure 13). Higher the weights better the urban environmental quality and vice-versa.

Most of the area (89\%) were having good environment conditions in 1982 only ward no. 78 Jagatpuri was under bad alarming condition because it had high built up lands with least open spaces. The northern areas are served by National Highway (NH-2) so, along this highway linear urban sprawl has been observed at a fast rate. The northastern area is near to the city centre so the unauthorized colonies have come up which degrade the urban environment. About 89\% area has good environmental condition, which are mainly urban villages, among some are uninhabited and having most of the area open or covered with food crops. DMC wards namely 72-Mandawali, 73Geeta Colony, 74-Laxmi Nagar, 79-Preet Vihar have fair environment condition. Geeta colony and Laxmi Nagar have high densely built up area but served by the major roads and are not affected by noise or foul smell, that's a fair environmental condition, is seen.

In 2003, little over two decades, the result of urban environment conditions indicate that comparatively most area $75 \%$ have good environment conditions while $22 \%$ is in poor condition and rest $3.5 \%$ is in bad alarming condition in East Delhi. This is mainly due to unplanned expansion on open vacant green areas excellent environment condition has been replaced by the poorer environmental conditions. In 1982 two villages are in excellent condition (Table 11). Out of eight village in 1981 five are becomes as Census town of Preet Vihar tehsil. The three villages situated along the river Yamuna has not been sprawled so the two villages Shakar Pur Barmad and Samas Pur are in very good condition and rest (Chilla saroda Khadar) is in fair condition. Among five Census towns Dallopura is in poor condition, while others are in desirable environment condition. These Census towns were in very good condition in 1982 thus the environment condition has been degraded in these areas very much due to outward expansion of Delhi When we talk about the environment condition in DMC wards, ward no 78 Jagatpuri which was in bad alarming condition in 1982 is same in 2003 followed by 76 Raghubarpura. Ward no 68 Dallo Pura ranked first in terms of good environmental condition followed by 69 Mayur Vihar, 74 Laxmi Nagar, 73 Geeta Colony, Shaikarpur, 79 Preet Vihar have fair environmental condition.

\section{Change in Quality of Urban Environment (1982-2003)}

Change is the Law of Nature but an urban environment condition is being changed rapidly due to interference of Man. The entire East Delhi has been changed significantly, mostly in negative direction (Table 12). The analysis shows that the area under poor environment condition has been increased, while bad alarming conditions have slightly increased in 2003 from 1982 (Figure 14). Most of the East district was in a better state of environment in 1982, but in 2003 things have been changed 


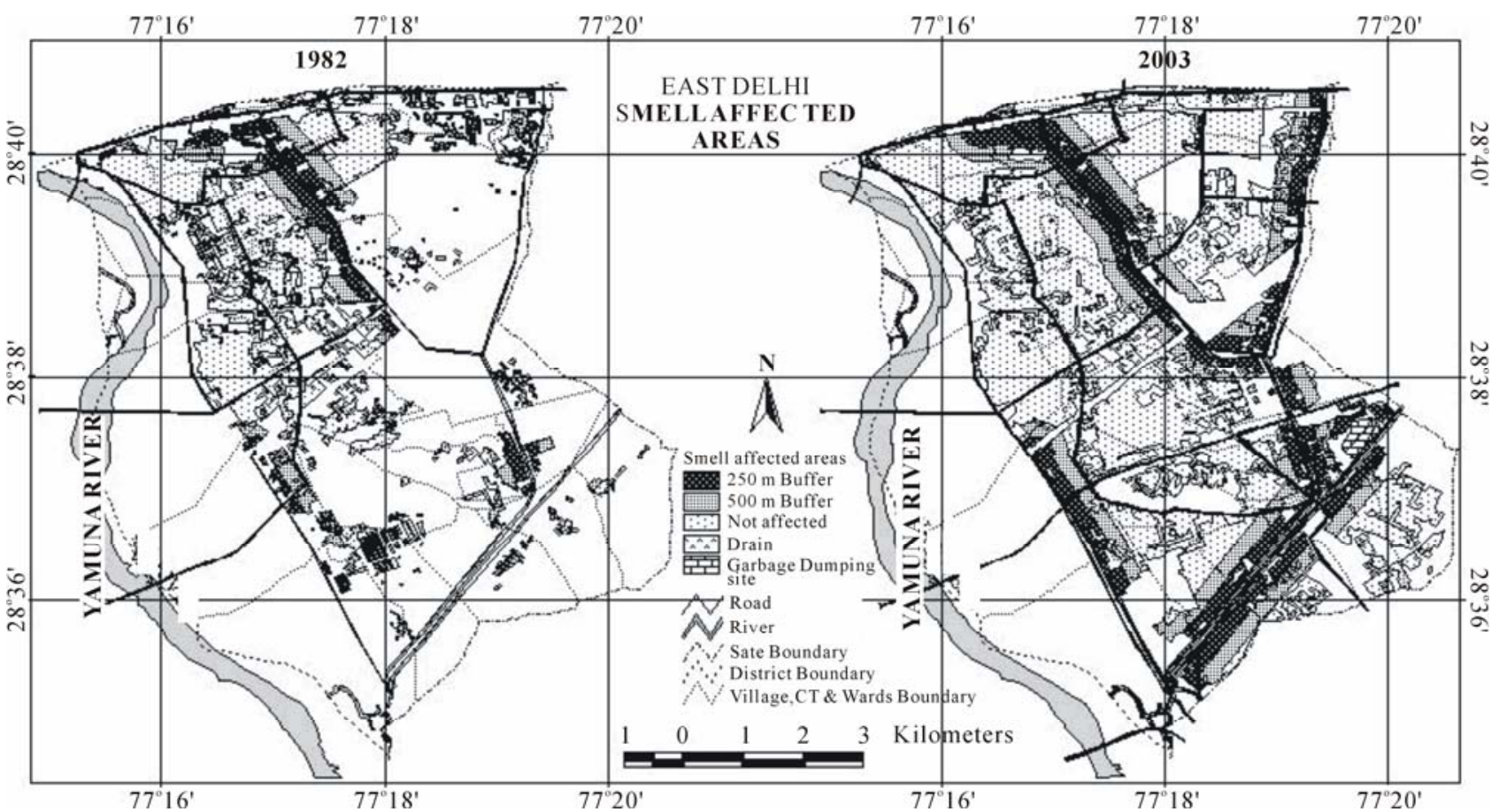

Figure 12. Foul smell affected areas, 1982 \& 2003.

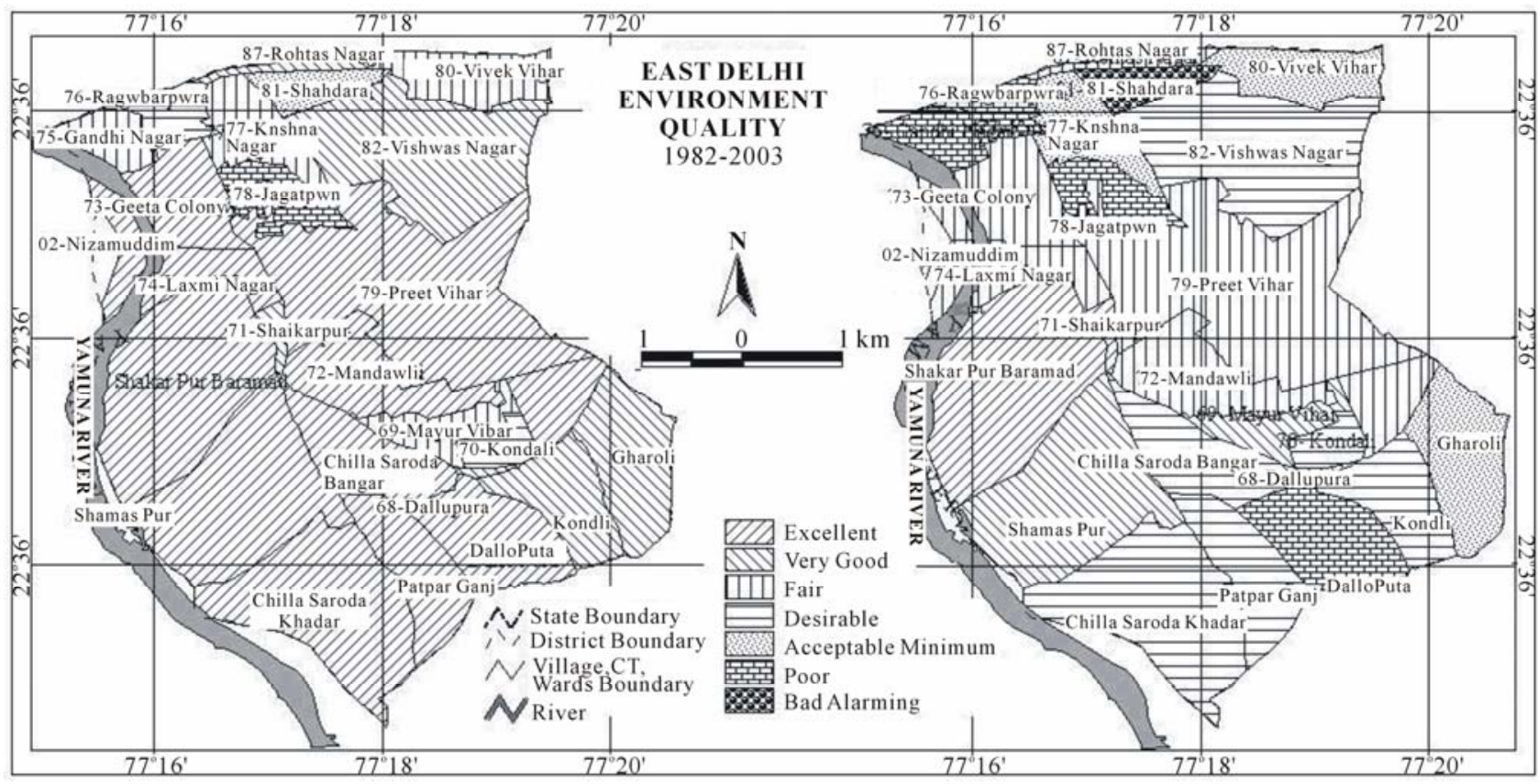

Figure 13. Quality of urban environment in east Delhi in 1982 \& 2003.

and now 50\% area is in very good, fair and desirable condition.

The study clearly shows that comparatively many areas in the East District of Delhi Metropolitan Region (DMR) have good environment condition. But in comparison to the year 1982, the quality of environment has been degraded in many areas in 2003. Major changes are observed in the southern part especially in all Census towns. The Census towns namely Dallupura and Patparganj are in very poor condition in the term environment degradation, while Kondali has minimum acceptable degradation in and rest areas show poor condition. The village Shakar Pur Barmad ranked first in terms of improvement in environment condition, which was ranked 


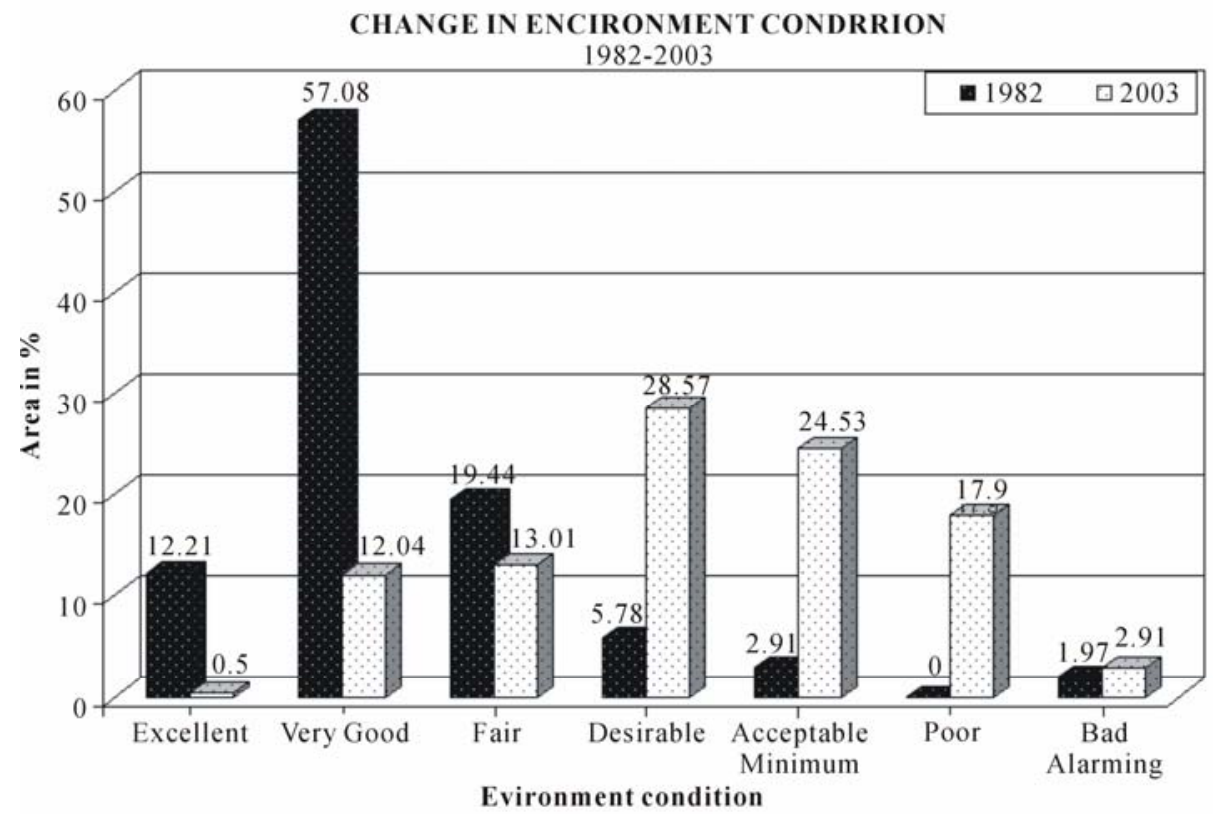

Figure 14. Area under different environment conditions, 1982 \& 2003.

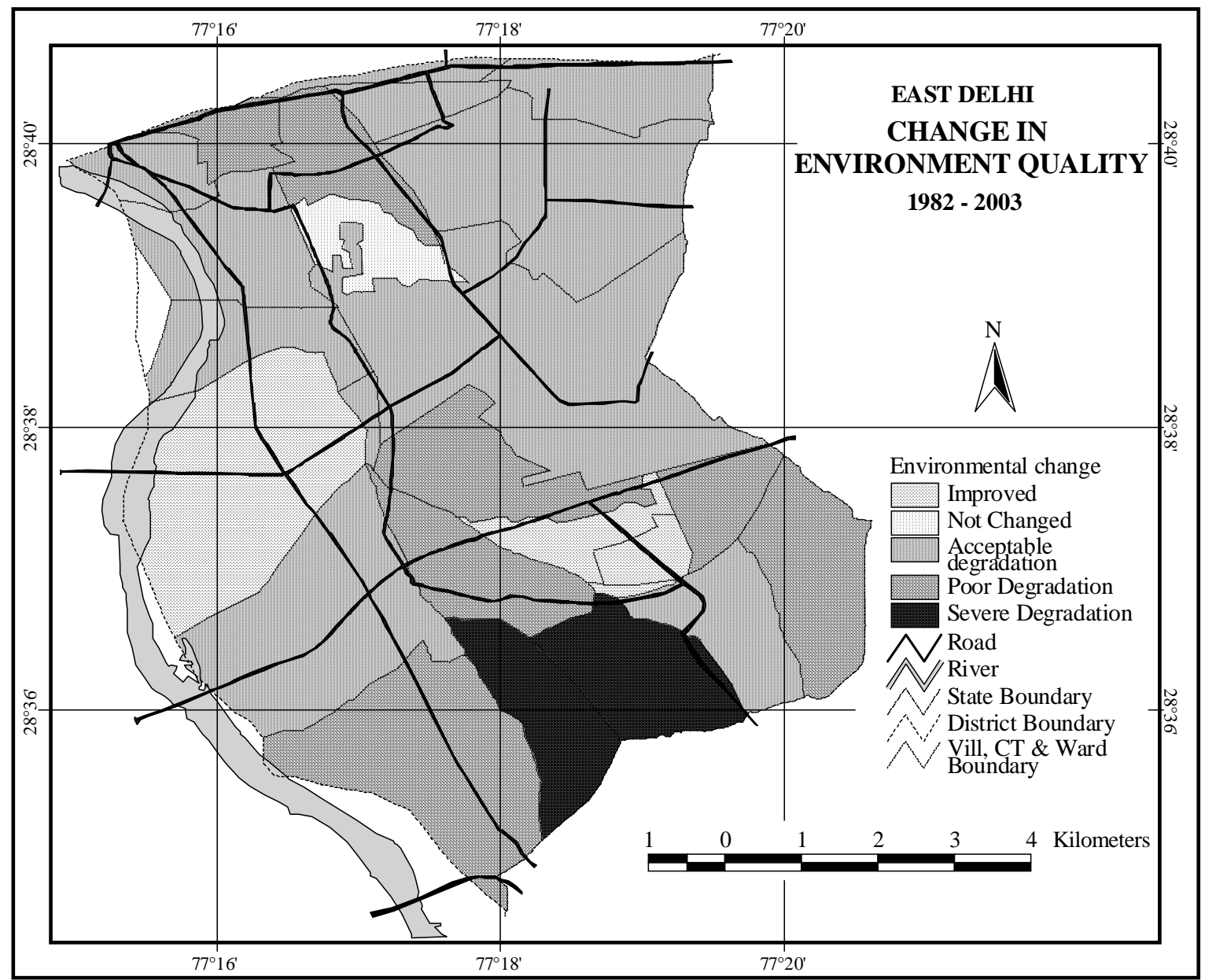

Figure 15. Change in environment quality, 1982-2003. 
Table 9. Environment quality parameters weights 1982.

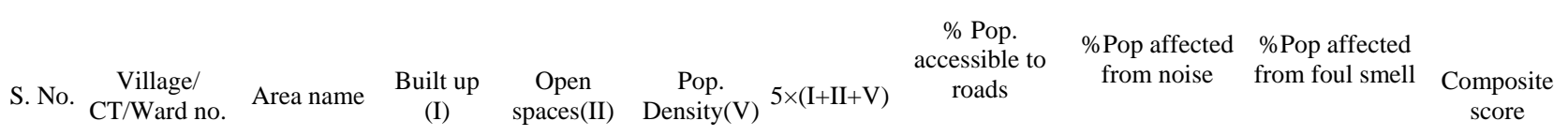

$250 \mathrm{~m} \quad 500 \mathrm{~m} \quad 40 \mathrm{~m} \quad 180 \mathrm{~m} \quad 250 \mathrm{~m} \quad 500 \mathrm{~m}$

\begin{tabular}{|c|c|c|c|c|c|c|c|c|c|c|c|c|c|}
\hline 1 & Vill & Shakar Pur & 5 & 4 & 5 & 70 & 4 & 1 & 10 & 5 & 10 & 5 & 105 \\
\hline 2 & Vill & Shamas Pur & 5 & 5 & 5 & 75 & 12 & 2 & 10 & 3 & 4 & 5 & 111 \\
\hline 3 & Vill & $\begin{array}{c}\text { Chilla S. } \\
\text { Khadar }\end{array}$ & 5 & 5 & 5 & 75 & 4 & 1 & 10 & 5 & 10 & 5 & 110 \\
\hline 4 & $\mathrm{CT}$ & $\begin{array}{c}\text { Chilla S. } \\
\text { Bangar }\end{array}$ & 5 & 5 & 5 & 75 & 12 & 2 & 10 & 3 & 10 & 5 & 117 \\
\hline 5 & $\mathrm{CT}$ & Patparganj & 5 & 5 & 5 & 75 & 4 & 1 & 10 & 5 & 10 & 5 & 110 \\
\hline 6 & $\mathrm{CT}$ & Dallopura & 5 & 5 & 5 & 75 & 4 & 1 & 8 & 5 & 10 & 5 & 108 \\
\hline 7 & $\mathrm{CT}$ & Kondli & 5 & 5 & 5 & 75 & 4 & 1 & 10 & 5 & 2 & 5 & 102 \\
\hline 8 & $\mathrm{CT}$ & Gharoli & 5 & 5 & 4 & 70 & 4 & 1 & 8 & 5 & 4 & 5 & 97 \\
\hline 9 & 68 & Dallopura & 5 & 5 & 3 & 65 & 4 & 1 & 8 & 5 & 10 & 4 & 97 \\
\hline 10 & 69 & Mayur Vihar & 5 & 5 & 2 & 60 & 4 & 1 & 10 & 5 & 10 & 3 & 93 \\
\hline 11 & 70 & Kondali & 4 & 4 & 3 & 55 & 4 & 1 & 10 & 5 & 6 & 3 & 84 \\
\hline 12 & 71 & Shaikarpur & 3 & 3 & 5 & 55 & 20 & 2 & 10 & 5 & 2 & 3 & 97 \\
\hline 13 & 72 & Mandawli & 4 & 5 & 5 & 70 & 8 & 2 & 10 & 2 & 10 & 3 & 105 \\
\hline 14 & 73 & Geeta Colony & 4 & 4 & 4 & 60 & 16 & 3 & 10 & 5 & 8 & 3 & 105 \\
\hline 15 & 74 & Laxmi Nagar & 5 & 4 & 3 & 60 & 16 & 3 & 10 & 5 & 10 & 3 & 107 \\
\hline 16 & 75 & Gandhi Nagar & 3 & 3 & 2 & 40 & 20 & 2 & 10 & 3 & 10 & 3 & 88 \\
\hline 17 & 76 & $\begin{array}{l}\text { Raghubar- } \\
\text { pura }\end{array}$ & 3 & 3 & 1 & 35 & 12 & 2 & 10 & 3 & 10 & 3 & 75 \\
\hline 18 & 77 & $\begin{array}{l}\text { Krishna Na- } \\
\text { gar }\end{array}$ & 3 & 3 & 3 & 45 & 20 & 4 & 10 & 4 & 8 & 2 & 93 \\
\hline 19 & 78 & Jagatpuri & 1 & 2 & 2 & 25 & 12 & 3 & 10 & 5 & 2 & 2 & 59 \\
\hline 20 & 79 & Preet Vihar & 5 & 5 & 4 & 70 & 12 & 3 & 10 & 4 & 8 & 2 & 109 \\
\hline 21 & 80 & $\begin{array}{l}\text { Vishwas } \\
\text { Nagar }\end{array}$ & 4 & 5 & 3 & 60 & 12 & 3 & 10 & 4 & 8 & 2 & 99 \\
\hline 22 & 81 & Shahdara & 3 & 2 & 2 & 35 & 16 & 3 & 10 & 1 & 6 & 1 & 72 \\
\hline 23 & 82 & Vivek Vihar & 4 & 4 & 3 & 55 & 12 & 2 & 10 & 1 & 8 & 1 & 89 \\
\hline 24 & 87 & Rohtas Nagar & 3 & 3 & 4 & 50 & 24 & 1 & 10 & 1 & 8 & 1 & 95 \\
\hline
\end{tabular}


Table 10. Environment quality parameters weights, 2003.

\begin{tabular}{|c|c|c|c|c|c|c|c|c|c|c|c|c|c|c|c|}
\hline \multirow[t]{2}{*}{$\begin{array}{l}\dot{z} \\
\dot{s}\end{array}$} & \multirow[t]{2}{*}{ 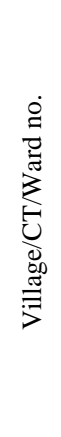 } & \multirow[t]{2}{*}{ 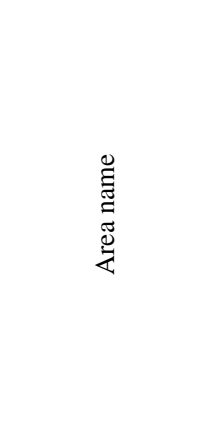 } & \multirow[t]{2}{*}{$\begin{array}{l}\ominus \\
\Xi \\
\Xi \\
\Xi \\
\Xi \\
\Xi\end{array}$} & \multirow[t]{2}{*}{ 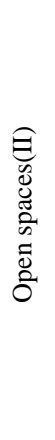 } & \multirow[t]{2}{*}{ 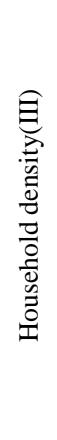 } & \multirow[t]{2}{*}{ 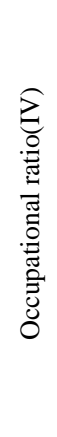 } & \multirow[t]{2}{*}{ 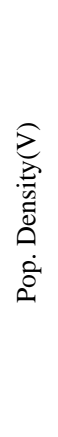 } & \multirow[t]{2}{*}{ 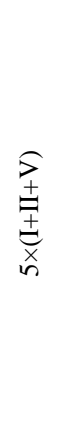 } & \multicolumn{2}{|c|}{ 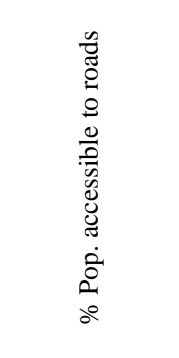 } & \multicolumn{2}{|c|}{ 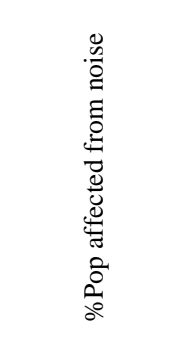 } & \multicolumn{2}{|c|}{ 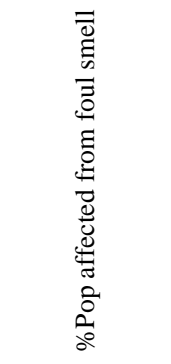 } & \multirow[t]{2}{*}{ 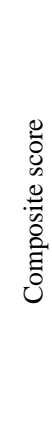 } \\
\hline & & & & & & & & & $250 \mathrm{~m}$ & $500 \mathrm{~m}$ & $40 \mathrm{~m}$ & $180 \mathrm{~m}$ & $250 \mathrm{~m}$ & $500 \mathrm{~m}$ & \\
\hline 1 & Vill & Shakar Pur & 4 & 4 & 5 & 4 & 5 & 65 & 12 & 3 & 10 & 5 & 5 & 4 & 110 \\
\hline 2 & Vill & Shamas Pur & 4 & 5 & 5 & 4 & 5 & 70 & 16 & 3 & 8 & 3 & 2 & 1 & 104 \\
\hline 3 & Vill & Chilla S. Khadar & 5 & 5 & 3 & 4 & 4 & 70 & 8 & 3 & 10 & 5 & 1 & 1 & 92 \\
\hline 4 & CT & Chilla S Bangar & 3 & 3 & 2 & 3 & 2 & 40 & 16 & 3 & 10 & 4 & 5 & 5 & 87 \\
\hline 5 & $\mathrm{CT}$ & Patparganj & 2 & 2 & 4 & 3 & 5 & 45 & 4 & 2 & 10 & 5 & 2 & 2 & 75 \\
\hline 6 & $\mathrm{CT}$ & Dallo Pura & 3 & 3 & 2 & 2 & 1 & 35 & 8 & 3 & 10 & 5 & 3 & 2 & 67 \\
\hline 7 & $\mathrm{CT}$ & Kondli & 3 & 3 & 4 & 4 & 4 & 50 & 8 & 3 & 10 & 5 & 3 & 3 & 89 \\
\hline 8 & $\mathrm{CT}$ & Gharoli & 4 & 4 & 1 & 3 & 2 & 50 & 4 & 2 & 10 & 5 & 4 & 4 & 75 \\
\hline 9 & 68 & Dallopura & 2 & 2 & 5 & 2 & 5 & 45 & 24 & 1 & 10 & 5 & 5 & 1 & 99 \\
\hline 10 & 69 & Mayur Vihar & 3 & 2 & 4 & 3 & 5 & 50 & 16 & 3 & 10 & 5 & 4 & 4 & 97 \\
\hline 11 & 70 & Kondali & 2 & 2 & 4 & 2 & 4 & 40 & 16 & 3 & 10 & 5 & 3 & 3 & 85 \\
\hline 12 & 71 & Shaikarpur & 1 & 1 & 5 & 2 & 5 & 35 & 20 & 2 & 10 & 5 & 5 & 5 & 94 \\
\hline 13 & 72 & Mandawli & 3 & 3 & 5 & 3 & 5 & 55 & 8 & 3 & 8 & 3 & 3 & 4 & 89 \\
\hline 14 & 73 & Geeta Colony & 3 & 3 & 4 & 2 & 4 & 50 & 16 & 3 & 10 & 5 & 5 & 5 & 97 \\
\hline 15 & 74 & Laxmi Nagar & 4 & 4 & 3 & 2 & 3 & 55 & 16 & 3 & 10 & 5 & 5 & 5 & 97 \\
\hline 16 & 75 & Gandhi Nagar & 3 & 3 & 1 & 1 & 1 & 35 & 20 & 2 & 8 & 2 & 5 & 5 & 74 \\
\hline 17 & 76 & Raghubarpura & 2 & 2 & 1 & 1 & 1 & 25 & 12 & 4 & 6 & 2 & 3 & 3 & 54 \\
\hline 18 & 77 & Krishna Nagar & 2 & 2 & 2 & 2 & 2 & 30 & 20 & 2 & 8 & 3 & 1 & 3 & 68 \\
\hline 19 & 78 & Jagatpuri & 1 & 1 & 1 & 2 & 1 & 15 & 12 & 3 & 10 & 5 & 4 & 3 & 59 \\
\hline 20 & 79 & Preet Vihar & 3 & 3 & 5 & 3 & 5 & 55 & 12 & 3 & 10 & 3 & 3 & 3 & 94 \\
\hline 21 & 80 & Vishwas Nagar & 3 & 3 & 4 & 2 & 4 & 50 & 12 & 3 & 10 & 4 & 3 & 3 & 86 \\
\hline 22 & 81 & Shahdara & 2 & 2 & 2 & 1 & 1 & 25 & 16 & 3 & 6 & 1 & 4 & 3 & 61 \\
\hline 23 & 82 & Vivek Vihar & 2 & 2 & 4 & 2 & 4 & 40 & 16 & 2 & 6 & 1 & 4 & 4 & 79 \\
\hline 24 & 87 & Rohtas Nagar & 3 & 3 & 3 & 1 & 3 & 45 & 24 & 1 & 10 & 1 & 4 & 4 & 87 \\
\hline
\end{tabular}


Table 11. Environment quality in $\mathbf{1 9 8 2}$ and 2003.

\begin{tabular}{|c|c|c|c|c|c|}
\hline \multirow{2}{*}{$\begin{array}{r}1982 \\
\text { Wards, CT,Villages }\end{array}$} & \multicolumn{3}{|c|}{2003} & \multirow{2}{*}{ Environment quality } & \multirow{2}{*}{ Composite score } \\
\hline & $\%$ Area & Wards, CT, Villages & \%Area & & \\
\hline Chilla S. Bangar(Vill), Shamas Pur(Vill) & 12.21 & & & Excellent & Above 110 \\
\hline $\begin{array}{l}\text { Chilla S. Khadar(Vill), Patparganj(Vill), } \\
\text { 79-Preet Vihar, Dallo Pura(Vill), } \\
\text { 74-Laxmi Nagar, } \\
\text { 72-Mandawli, } \\
\text { 73-Geeta Colony, Shakar Pur(Vill), } \\
\text { Kondli(Vill) }\end{array}$ & 57.08 & $\begin{array}{c}\text { Shakar Pur(Vill), Shamas } \\
\text { Pur(Vill) }\end{array}$ & 18.83 & Very Good & $100-110$ \\
\hline $\begin{array}{l}\text { 80-Vishwas Nagar, Gharoli(Vill), } \\
\text { 68-Dallopura, } \\
\text { 71-Shaikarpur, } \\
\text { 87-Rohtas Nagar, 69-Mayur Vihar, } \\
\text { 77-Krishna Nagar }\end{array}$ & 19.44 & $\begin{array}{l}\text { 68-Dallopura, } \\
\text { 69-Mayur Vihar, } \\
\text { 74-Laxmi Nagar, } \\
\text { 73-Geeta Colony, } \\
\text { 71-Shaikarpur, } \\
\text { 79-Preet Vihar, } \\
\text { Chilla S Khadar(Vill) }\end{array}$ & 32.14 & Fair & $90-100$ \\
\hline $\begin{array}{l}\text { 82-Vivek Vihar, } \\
\text { 75-Gandhi Nagar, } \\
\text { 70-Kondali }\end{array}$ & 5.78 & $\begin{array}{l}\text { Kondli(CT), } \\
\text { 72-Mandawli, } \\
\text { 87-Rohtas Nagar, } \\
\text { Chilla S Bangar(CT), } \\
\text { 80-Vishwas Nagar, } \\
\text { 70-Kondali }\end{array}$ & 24.06 & Desirable & $80-90$ \\
\hline \multirow[t]{2}{*}{$\begin{array}{l}\text { 76-Raghubarpura, } \\
\text { 81-Shahdara }\end{array}$} & 2.91 & $\begin{array}{l}\text { 82-Vivek Vihar, } \\
\text { Gharoli(CT), Patparganj, } \\
\text { 75-Gandhi Nagar }\end{array}$ & 12.59 & Acceptable Minimum & $70-80$ \\
\hline & & $\begin{array}{l}\text { 77-Krishna Nagar, } \\
\text { Dallo Pura(CT), } \\
\text { 81-Shahdara }\end{array}$ & 8.33 & Poor & $60-70$ \\
\hline 78-Jagatpuri & 1.97 & $\begin{array}{l}\text { 78-Jagatpuri, } \\
\text { 76-Raghubarpura }\end{array}$ & 3.44 & Bad Alarming & Below 60 \\
\hline
\end{tabular}

as very good in 1982, changed to excellent condition in 2003. All DMC wards are slightly degraded except Krishna Nagar and Raghubarpura in North and Mandawli in South. The DMC ward Jagatpuri has not shown any change in the two decades from 1982 to 2003 (Figure 15).

\section{Public Participation Approach and the Urban Environmental Quality}

It is seen that better urban environmental quality in some districts of Delhi is achieved after public battles, between municipal authorities like New Delhi Municipal Corporation (NDMC), Municipal Corporation of Delhi (MCD) and planning authority like Delhi Development Authority (DDA) and between various groups of Resident's Welfare Associations (RWA). Arguments that stem from conflicts of interest create different types of mechanisms for dialogue, which are generally referred to as "public participation" or "public involvement." In recent years there has been a growing public awareness of the need to play a more active role in designing the urban environment in which we all live and breathes.

As it is said earlier that most of the world's population chooses to live in cities. Environmental quality, in the broadest sense of the term, is closely related to the quality of life of the urban resident. The two actors that have the strongest influence on the quality of life in the urban environment are 1) the residents in the way they relate to environmental issues and 2) policy-makers and decision-makers-in the way they plan and implement a series of policy measures that could potentially improve, or destroy, the urban quality of life.

Planning decisions that influence the urban environment are usually characterized by the fact that they are made by the administration, with the help of some experts and urban planners. Residents play a minor role and their ability to influence and change decisions that dictate the quality of their lives is limited. Decision-makers, or planners, tend to weigh various alternatives and 
Table 12. Change in urban environment (1982-2003).

\begin{tabular}{|c|c|c|c|}
\hline $\begin{array}{l}\text { Villages, CTs \& } \\
\text { DMC wards }\end{array}$ & $\begin{array}{c}\text { Environment Quality } \\
\text { In } 1982\end{array}$ & $\begin{array}{l}\text { Environment Quality } \\
\text { In } 2003\end{array}$ & Change in 1982-2003 \\
\hline Shakar Pur Baramad & Very Good & Excellent & Improved \\
\hline Shamas Pur & Excellent & Very Good & Acceptable degradation \\
\hline Chilla Saroda Khadar & Excellent & Fair & Poor Degradation \\
\hline Chilla Saroda Bangar & Excellent & Desirable & Poor Degradation \\
\hline Patparganj & Excellent & Acceptable Minimum & Severe Degradation \\
\hline Dallopura & Very Good & Poor & Severe Degradation \\
\hline Kondli & Very Good & Desirable & Acceptable degradation \\
\hline Gharoli & Fair & Acceptable Minimum & Poor Degradation \\
\hline 68-Dallopura & Fair & Fair & Improved \\
\hline 69-Mayur Vihar & Fair & Fair & Improved \\
\hline 70-Kondali & Desirable & Desirable & Improved \\
\hline 71-Shaikarpur & Fair & Fair & Acceptable degradation \\
\hline 72-Mandawli & Very Good & Desirable & Poor Degradation \\
\hline 73-Geeta Colony & Very Good & Fair & Acceptable degradation \\
\hline 74-Laxmi Nagar & Very Good & Fair & Acceptable degradation \\
\hline 75-Gandhi Nagar & Desirable & Acceptable Minimum & Acceptable degradation \\
\hline 76-Raghubarpura & Acceptable Minimum & Bad Alarming & Poor Degradation \\
\hline 77-Krishna Nagar & Fair & Poor & Poor Degradation \\
\hline 78-Jagatpuri & Bad Alarming & Bad Alarming & Not Changed \\
\hline 79-Preet Vihar & Very Good & Fair & Acceptable degradation \\
\hline 80-Vishwas Nagar & Fair & Desirable & Acceptable degradation \\
\hline 81-Shahdara & Acceptable Minimum & Poor & Acceptable degradation \\
\hline 82-Vivek Vihar & Desirable & Acceptable Minimum & Acceptable degradation \\
\hline 87-Rohtas Nagar & Fair & Desirable & Acceptable degradation \\
\hline
\end{tabular}

choose the one they prefer in terms of "the public interest," as they perceive it. This concept would seem to reflect a balance between the needs of people and groups of citizens often defined as "narrow interests" and between "the greater good," as perceived by policymakers. Realization of that interest is the rational basis underlying urban planning and development. But environmental quality is often trampled in the name of "the public interest" and various populations in the city are getting affected in its wake.

Over the last few decade city like Delhi has undergone impressive development in the public's awareness of environmental issues and planning, and the ability of individuals, groups and communities to influence urban environmental quality through planning and the use of policy tools. This is seen mainly with the increase in literacy and coming up of various NGOs. On the other hand, there are still many people who are not cognizant of the importance of planning and its impact on the urban environment [19]. Everyone wants to have a spacious apartment, and clean air. The question is, what is "clean" and who gets to define it; and what is the price we are willing to pay in order to reduce open spaces in the city for the sake of constantly increasing the size of the average housing unit? These are clearly questions of values, and therefore the answers cannot be based solely on the opinions of environmental experts, no matter how professional and well trained they may be. Issues pertaining 
to public participation are also a matter of great concern. They are based on an acceptance of democratic and pluralistic values, without which there is no conceptual basis for public participation. The idea that the public has a fundamental right to be involved in the decisions that affect their lives is a values statement, by definition. Since urban environmental quality is determined, to a large extent, by planners, decision-makers and policymakers who influence the quality of life of each individual, the public has the right to have a say in these matters. Through involvement and participation, the public should have an influence on planning, the decisions that are made and policies that are formulated for the better urban environmental quality.

\section{Conclusions}

As the urban areas are growing at a fast rate, especially in metropolitan cities like Delhi and Mumbai etc. so up-to-date information on land and people is needed to monitor and manage the quality of urban environmental. The paper shows that the East Delhi has experienced environmental deterioration in two decades especially in southern periphery due to unplanned urban expansion adjoining to the state of Uttar Pradesh. Physical environment is to be improved in north-western part, by urban renewal scheme by providing greenery and improvement of traffic movement. The physical environment in many slums areas is poor and they should be provided with necessary services like water supply, sanitation, sewerage and accessibility to roads. Remote sensing data and GIS technique is very useful for extraction of information like built-up areas, open green space, urban land use mapping that are important attribute for assessing the urban environmental quality for a big urban agglomeration. The fast growing areas in Census towns located in southern part should be properly planned and the infrastructure and other recreational facilities should be improved in these areas so as to improve the environmental quality of these urban settings. There should be a larger role of public for planning and designing the urban land use pattern and other associated activities in order to have a healthy urban environment for the good quality of life.

\section{References}

[1] A. Rahman, M. Netzband, S. Alka and M. Javed, “An assessment of Urban Environmental Issues Using Remote Sensing and GIS Techniques an Integrated Approach: A Case Study: Delhi, India,” In: A. de Sherbinin, A. Rahman, A. Barbieri, J. C. Fosto and Y. Zhu, Eds., Urban Population-Environment Dynamics in the Developing World: Case Studies an Lessons Learned, International
Cooperation in National Research in Demography (CICRED), Paris, 2009, pp. 181-211.

[2] “Census of India,” New Delhi, 1991. www.censusindia. net

[3] “Census of India,” New Delhi, 2001, www.censusindia. net

[4] S. Fazal, "Land Reorganization Study along Major Roads,” Land Use Policy, Vol. 18, No. 2, 2001, pp. 191-199. doi:10.1016/S0264-8377(01)00007-2

[5] B. Mishra, R. B. Singh and M. Anupama, "Delhi Metropolis: Housing and Quality of Life,” In: R. P. Mishra, Million Cities of India, Vol. 1, 2001, pp. 196-228.

[6] A. Rahman, “Application of Remote Sensing and GIS Technique for Urban Environmental Management and Sustainable Development of Delhi, India,” In: M. Netzband, W. L. Stefnow and C L. Reman, Eds., Applied Remote Sensing for Urban Planning, Governance and Sustainability, Springer-Verlag Publishes, Berlin, 2007, pp. 165- 197. doi:10.1007/978-3-540-68009-3_8

[7] S. Sengupta and P. Venkatachalam, "Assessment of Social and Physical Environment of a Planned Town with Geographical Information System: A Case of Durgapur, West Bengal, India,” In: B. S. Sokhi and S. M. Rashid, Eds., Remote Sensing of Urban Environment, 1999, pp. 196-203.

[8] MoEF (Ministry of Environment and Forest), "White Paper on Pollution in Delhi with Action Plan," Government of India, 1997.

[9] J. Nichol and M. S. Wong, "Mapping and Modelling of Urban Environment Quality in Hongkong,” 2004.

[10] ISRO, “Urban Planning Using IRS-1C Data,” Banglore, 2005.

[11] R. S. Rathi and R. R. Vatsvani, "Digital Mapping of Urban/Sub-Urban Environment of Dehradun Using SPOT Data,” In: B. S. Sokhi and S. M. Rashid, Eds., Remote Sensing of Urban Environment, 1999, pp. 123-136.

[12] P. V. P. C. Prasad, "Environmental Impact Assessment," Project Work, HUSA, IIRS, NRSA, 1990.

[13] J. R. Eastman, "Multi-Criteria Evaluation and GIS,” In: P. A. Langley, M. F. Goodchild, D. J. Maguire and D. W. Rhind, Eds., Geographical Information System, Vol. 1, Principals and Technical Issues, 2002.

[14] K. K. Talukdar and B. Ramesh, “Assessment of Urban Environment Quality Using Large Scale Aerial Photographs-Case Study in Dwarka, Delhi,” In: Proceedings, Indian Society of Remote Sensing Silver Jubilee Symposium 1994-1995, Indian Institute of Remote Sensing, Dehradun, 1995, pp. 250-257.

[15] Economic Survey of Delhi, 1999-2000. http://delhiplanning.nic.in/Economic\%20Survey/chapter_3.htm

[16] I. Kimhi, “Urban Environmental Quality,” The Centre for Environmental Policy Studies Series \#12, the Jerusalem Institute for Israel Studies, Jerusalem, 2005. http://www.j iis.org.il

[17] CSE (Centre for Science and Environment), "A people’s model to clean air: Steering the way, Down to Earth," 
New Delhi, Vol. 11, No. 12, November 2002.

[18] J. E. Hardoy, D. Mitlin and D. Satterthwaite, "Environmental Problems in Third World Cities," Earthscan Publication, London, 1997.
[19] B. N. Haack, “Urban Analysis and Planning,” In: Manual of Photographic Interpretation, 2nd Edition, W. R. Philipson, Editor-in-Chief, ASPRS, 1997. 